\title{
Priority questions in multidisciplinary drought research
}

\author{
Miroslav Trnka ${ }^{1,2, *}$, Michael Hayes, František Jurečka, Lenka Bartošová, \\ Martha Anderson, Rudolf Brázdil, Jesslyn Brown, Jesus J. Camarero, \\ Pavel Cudlín, Petr Dobrovolný, Josef Eitzinger, Song Feng, Taryn Finnessey, \\ Gregor Gregorič, Petr Havlik, Christopher Hain, Ian Holman, David Johnson, \\ Kurt Christian Kersebaum, Fredrik Charpentier Ljungqvist, Jürg Luterbacher, \\ Fabio Micale, Claudia Hartl-Meier, Martin Možný, Pavol Nejedlik, \\ Jørgen Eivind Olesen, Margarita Ruiz-Ramos, Reimund P. Rötter, Gabriel Senay, \\ Sergio M. Vicente-Serrano, Mark Svoboda, Andreja Susnik, Tsegaye Tadesse, \\ Adam Vizina, Brian Wardlow, Zdeněk Žalud, Ulf Büntgen \\ ${ }^{1}$ Global Change Research Institute AS CR v.v.i., Bělidla 986/4b, Brno, 603 00, Czech Republic \\ ${ }^{2}$ Mendel University in Brno, Institute of Agrosystems and Bioclimatology, Zemědělská 1, Brno, 613 00, Czech Republic \\ Full affiliations in Supplement 1 at www.int-res.com/articles/suppl/c075p241_supp.pdf
}

\begin{abstract}
Addressing timely and relevant questions across a multitude of spatio-temporal scales, state-of-the-art interdisciplinary drought research will likely increase in importance under projected climate change. Given the complexity of the various direct and indirect causes and consequences of a drier world, scientific tasks need to be coordinated efficiently. Drought-related research endeavors ranging from individual projects to global initiatives therefore require prioritization. Here, we present 60 priority questions for optimizing future drought research. This topical catalogue reflects the experience of 65 scholars from 21 countries and almost 20 fields of research in both natural sciences and the humanities. The set of drought-related questions primarily covers drought monitoring, impacts, forecasting, climatology, adaptation, as well as planning and policy. The questions highlight the increasingly important role of remote sensing techniques in drought monitoring, importance of drought forecasting and understanding the relationships between drought parameters and drought impacts, but also challenges of drought adaptation and preparedness policies.
\end{abstract}

KEY WORDS: Drought climatology · Climate change $\cdot$ Drought monitoring $\cdot$ Drought forecasting · Drought adaptation $\cdot$ Drought planning $\cdot$ Drought mitigation

\section{INTRODUCTION}

Among climate variables, drought has had the largest adverse impacts for mankind throughout history. Examples of severe harvest failures and famines are abundant (Ljungqvist 2017) and include the collapse of the Akkadian Empire in the Middle East ca. 4200 yr ago (Anderson et al. 2007) or the medieval 'mega-droughts' hitting Classic Maya Civilization

\footnotetext{
${ }^{*}$ Corresponding author: mirek_trnka@yahoo.com
}

(Douglas et al. 2016) and the Ancestral Pueblo culture (Bocinsky \& Kohler 2014) in today's Mexico and the US. More recent examples include the Little Ice Age monsoon failures that caused famines with countless deaths in China (Yang et al. 2014), India (Sinha et al. 2011), and Southeast Asia (Buckley et al. 2010) and the El Niño-related droughts that caused tens of millions of famine-related deaths in the late $19^{\text {th }}$ century (Davis 2001). During the period

(C) The authors and outside the USA The US Government 2018. Open Access under Creative Commons by Attribution Licence. Use, distribution and reproduction are unrestricted. Authors and original publication must be credited.

Publisher: Inter-Research · www.int-res.com 
1995-2015, droughts affected over 1 billion people (CRED \& UNISDR 2016), which more than justifies research addressing future droughts and their potential impacts.

Research on droughts is interdisciplinary, requiring meteorological, climatological, hydrological, modeling, and socio-economic expertise (Wilhite 2000). Thus, drought research covers a wide range of topics, including coupled atmosphere-ocean mechanisms and processes (e.g. García-Herrera et al. 2007, Barlow 2012); observations of the spatio-temporal variability and trends in drought frequency and severity (Hoerling et al. 2012, Sheffield et al. 2012, Spinoni et al. 2015, Ljungqvist et al. 2016); and impacts on agriculture (Lobell et al. 2015, Lesk et al. 2016), hydrology (Fleig et al. 2006), the environment (Nicholson et al. 1998, Ciais et al. 2005, Allen et al. 2010, Camarero et al. 2013), public health and famine (Mortimore 1989, Nathan et al. 1996, Haile 2005), power generation (Beniston 2012, Jerez et al. 2013), and transportation (Marengo et al. 2011).

Understanding the indispensable role of drought proxy data (e.g. tree rings, historical documents, speleothems, and lake sediments) is critical, as the drought frequency in records is relatively low and instrumental data records can be too short. Thus, studies have identified the variable spatial and temporal severity of drought in different regions using paleoclimatic records (E. Cook et al. 1999, 2010, 2015, Pfister et al. 2006, Esper et al. 2007, Büntgen et al. 2010, Camuffo et al. 2010, Domínguez-Castro et al. 2012, Brázdil et al. 2013, B. Cook et al. 2014, Smerdon et al. 2017), which allow a better understanding of drought severity in a historical context.

Uncertainties exist in recent drought severity trends (Vicente-Serrano et al. 2014, Van Loon et al. 2016). The last AR5 IPCC (Hartmann 2015) report stated a medium level of confidence in drought trends at the global scale because of the large data and model uncertainties associated with objective drought quantification (e.g. Seneviratne et al. 2012, Trenberth et al. 2014). Some recent studies (Sheffield et al. 2012, Greve et al. 2014, Nasrollahi et al. 2015) indicate that the 'wet-getting-wetter and dry-getting-drier' paradigm (Held \& Soden 2006) is too simplistic and that drought-related changes might be more complex during global warming than previously thought (Ljungqvist et al. 2016).

Independent of recent global-scale drought trends, evidence of increased drought severity exists in different regions as a consequence of precipitation decreases (e.g. Hoerling et al. 2012) and/or increased atmospheric evaporation (Vicente-Serrano et al.
2014, Trnka et al. 2015). These trends, in combination with increased societal vulnerability, have led to a noticeable increase in drought-related societal impacts (Meehl et al. 2000, Lesk et al. 2016). The environmental impacts of droughts have also increased and are attributed to the enhancement of drought severity by climate change (Breshears et al. 2005, van Mantgem et al. 2009, Allen et al. 2010, Brázdil et al. 2015). Therefore, improving our understanding of the resistance, resilience, and vulnerability of different economic sectors under current and future climate scenarios is important. In-depth research of drought phenomena will improve the planning and societal responses to drought (Wilhite 1991). Prior drought research has led to improved drought monitoring and early warning systems (Svoboda et al. 2002), reducing ecosystem vulnerability via management strategies (López et al. 2009) and introduction of cropping systems, crops, and cultivars with high drought resilience (Olesen et al. 2011).

What are the important questions and challenges related to future drought studies and projects? Here, we present the outcomes of focus group discussions of experts from various sectors and disciplines in order to identify a set of priority questions in multidisciplinary drought research. This methodological approach has been applied to advance the field of multiple disciplines (Sutherland et al. 2006, 2009, 2011, 2013, Pretty et al. 2010, Grierson et al. 2011, Petrokofsky et al. 2013, Walzer et al. 2013, Seddon et al. 2014, Armstrong et al. 2017). Most of these studies initiated discussion amongst researchers, but more importantly 'mapped' knowledge gaps, which is particularly important for stakeholders and funders. To serve a similar purpose, we present a synthesis of drought-related workshops held at the Global Change Research Institute, Czech Academy of Sciences, which have provided 60 priority research questions to guide future scientific efforts.

\section{MATERIALS AND METHODS}

At the first Global Change Research Institute workshop in July 2014, a questionnaire and a set of instructions were developed (see Supplement 1 at www. int-res.com/articles/suppl/c075p241_supp/) along with the work plan (Fig. 1) to foster the formulation of research questions, and an open application process followed. The authors contacted research organizations and individual researchers by email, asking them to contribute to the study based on their past publication record or current work on drought- 


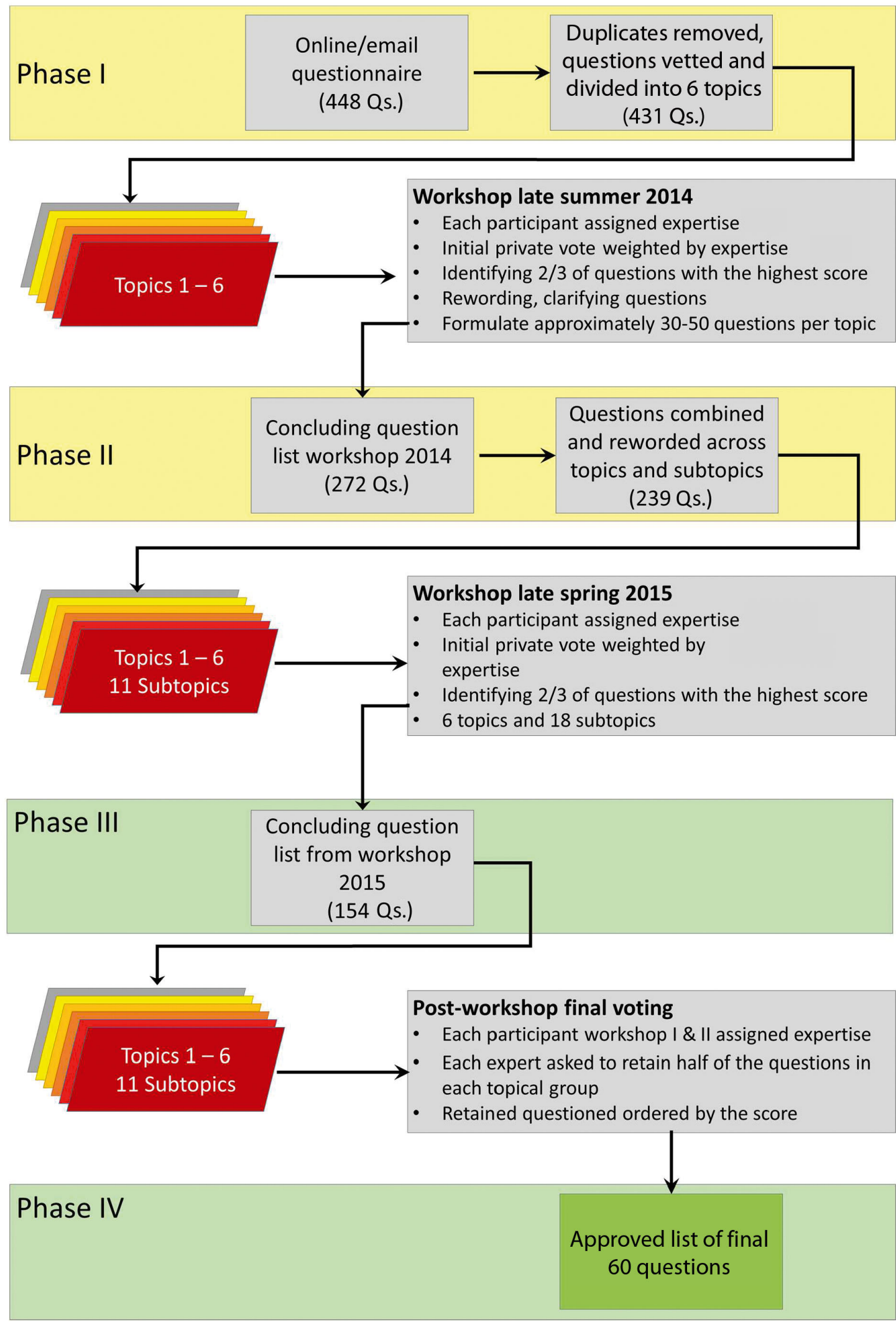

Fig. 1. Schematic overview of the procedure used to reduce 448 submitted questions to the final 60 highest-priority questions in interdisciplinary drought research 
related issues. The authors attempted to ensure the disciplinary and geographical representativeness of the participants. The contacted researchers/organizations were encouraged to disseminate the questionnaire to partner organizations over a period of 2 months. This approach followed a modified chain referral method to strategically identify participants for the questionnaire (Penrod et al. 2003, Sutherland et al. 2011). The questionnaires were screened by the lead author to determine the clarity of the proposed questions, and the participants were contacted for amendments when necessary. Phase I (Fig. 1) resulted in 448 questions, which were submitted during June-August 2014, either directly during the workshop or online from 65 individuals, research institutes, and organizations in 21 countries across Europe, Asia, Australia, and the Americas, along with several drought researchers actively focusing on Africa. The 448 questions were screened by the 4 lead authors for redundancy, and the number of questions was reduced to 431. The 431 questions were then divided into 6 topics (Table 1). In the Phase I, each expert who contributed research questions was asked to identify two-thirds of the questions as 'higher priority.' This process resulted in a set of 272 questions. During Phase II, the remaining questions were compared by the first 4 authors for content, and semantically similar questions were reformulated and merged, which decreased the number of questions to 239. The questions that were similar were combined, and the language and clarity of the questions were reviewed by the 4 lead authors. In Phase III, the 239 questions were evaluated by a panel of 18 experts during the second drought workshop in June 2015 using a 6-point scale. Their responses to each question were made comparable by standardizing the total number of points given by each expert to the median of all the experts to maintain approximate parity among the panel members.

Because the questions represented a fairly broad range of research fields, the expertise of each expert was considered and double weight was given to

Table 1. Research topics and subtopics with the numbers of questions in the individual phases. The sequence of the phases for prioritizing research questions can be seen in Fig. 1, and includes Phase I: collation of all questions with simple redundancy check; Phase II: first round of question ranking with $2 / 3$ of questions retained and combined, questions organized according to topic; Phase III: second round of ranking with $2 / 3$ of questions retained, subtopics introduced; Phase IV: final voting to determine the top 60 questions

\begin{tabular}{|c|c|c|c|c|c|}
\hline Topic & Subtopics & $\begin{array}{l}\text { Phase } \\
\text { I }\end{array}$ & $\begin{array}{l}\text { Phase } \\
\text { II }\end{array}$ & $\begin{array}{c}\text { Phase } \\
\text { III }\end{array}$ & $\begin{array}{c}\text { Phase IV } \\
\text { final } \\
\text { questions }\end{array}$ \\
\hline \multirow[t]{3}{*}{ 1. Drought monitoring } & & - & 48 & 28 & 7 \\
\hline & $\begin{array}{l}\text { Monitoring drought severity, } \\
\text { frequency, and duration }\end{array}$ & - & - & 8 & 3 \\
\hline & $\begin{array}{l}\text { Understanding user applications } \\
\text { of drought monitoring tools }\end{array}$ & - & - & 20 & 4 \\
\hline \multirow[t]{5}{*}{ 2. Drought impacts } & & - & 76 & 56 & 19 \\
\hline & Overall & - & - & 23 & 7 \\
\hline & Crops and plants & - & - & 21 & 6 \\
\hline & Trees and forests & - & - & 8 & 2 \\
\hline & Socio-economic impacts & - & - & 4 & 4 \\
\hline 3. Drought forecasting and prediction & & - & 19 & 10 & 3 \\
\hline \multirow[t]{3}{*}{ 4. Drought climatology } & & - & 38 & 17 & 15 \\
\hline & Climatology and paleoclimatology & - & - & 10 & 9 \\
\hline & Climate change & - & - & 7 & 6 \\
\hline 5. Adaptation strategies for drought & & - & 40 & 36 & 12 \\
\hline 6. Drought planning and policy & & - & 18 & 7 & 4 \\
\hline In total & & $431^{\mathrm{a}}$ & $239^{\mathrm{b}}$ & 154 & 60 \\
\hline
\end{tabular}



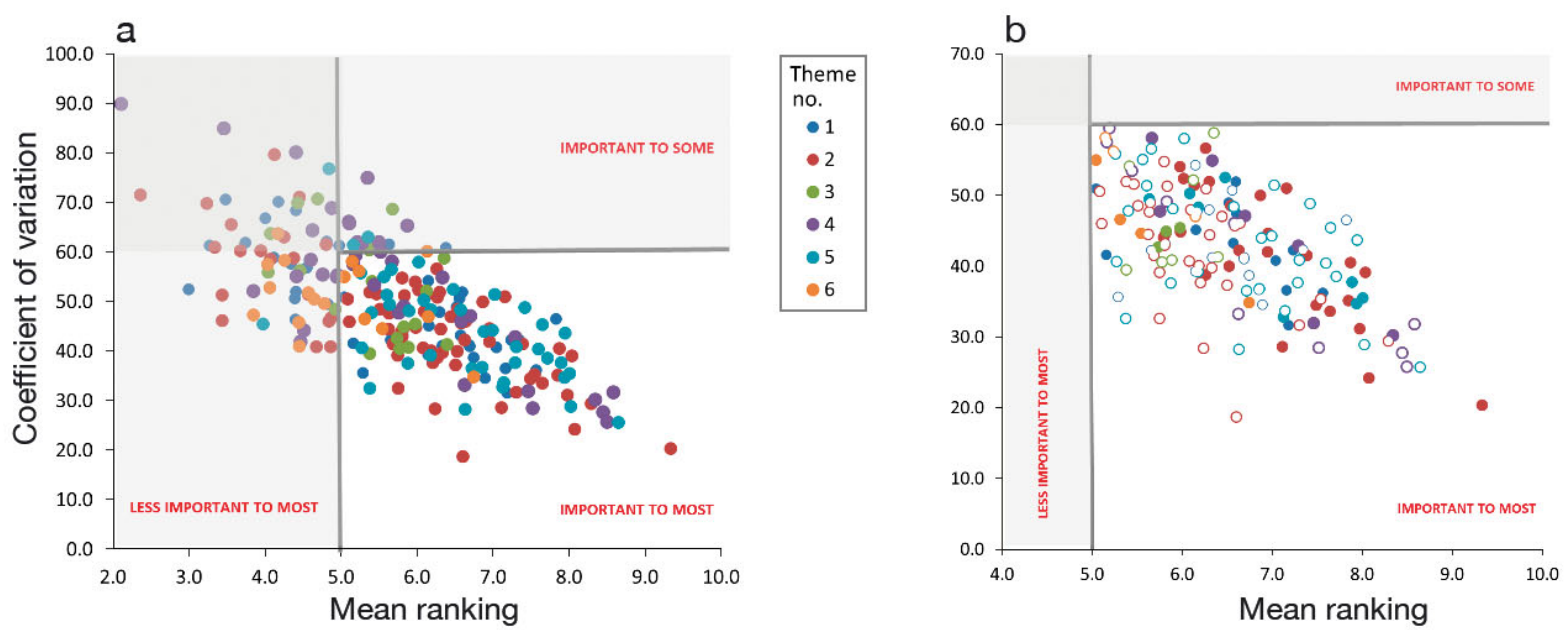

Fig. 2. (a) Scoring results of the individual questions after normalization and weighting by expertise. 1: Drought monitoring; 2: Drought impacts; 3: Drought forecasting; 4: Drought climatology; 5: Adaptation to drought; 6: Drought planning and policy. The shading shows questions that were not considered further based on the mean ranking of the responses and coefficient of variation. (b) Original scoring of set of 154 questions in Phase III. The questions that were most frequently retained are left as solid colors and represent the final set of 60 questions. The open dots represent questions that were considered less important within the given theme

questions related to their self-selected research strengths compared to those related to other subtopics. The top scoring 154 questions were selected (see Supplement 4) by participants of the 2015 workshop. During Phase IV in early 2016, the experts involved in any of the previous phases were asked a final time to identify half of the questions within each theme that they considered 'top priority' and to remove the rest. In all phases, senior researchers (lab leaders, professors, etc.) dominated the field of experts; however, several accomplished younger researchers with 6-10 yr of research experience were also among the group. Based on their evaluation, the final list of 60 questions was compiled based on the priority ranking during Phase IV. These questions are identified in the text by reference to their number (e.g. [Q1]) and are not ranked but rather grouped thematically.

Fig. 1 and Table 1 show how the number of questions was refined through each of the individual phases during the evaluation process. In Phase I, the number of questions was reduced by approximately $45 \%$ and grouped into individual main topics. The scores and their coefficients of variation (Fig. 2) show that the majority of questions were considered important across themes (i.e. experts with various fields of expertise considered similar questions to be important). A lower ranking of questions in comparison with other themes only occurred in the 'Drought planning and policy' topic. Although experts in 'drought policy' ranked other themes relatively high (and considered them important as crucial inputs to proper drought policies), the drought policy-related questions were not viewed as critically important by the majority of the other experts relative to the other themes. However, this imbalance was evened out in Phase IV, when more than half of the remaining questions were retained. The final set of 60 priority questions is presented in Box 1.

\section{RESULTS AND DISCUSSION}

\subsection{Monitoring}

Drought monitoring is a critical component for drought early warning systems and a key instrument in timely risk management and drought planning (WMO 2006, WMO \& GWP 2016). However, the methods used by various countries for drought monitoring range from virtually no systematic monitoring, through simple drought indices (or even percentiles of precipitation) to complex process-based modeling tools. Few studies have analyzed the ability of different drought indices to identify impacts in a variety of sectors (e.g. Hlavinka et al. 2009, Vicente-Serrano et al. 2012, Bachmair et al. 2015, Stagge et al. 2015, Brázdil et al. 2016). Overall results show that drought indices calculated on different time scales can be successfully used in the identification of different impacts, but a critical need remains for understanding the pros and cons of available methods, as well as the pros and cons of simple versus complex modeling, for the wide variety of sectors and decision making [Q1]. 


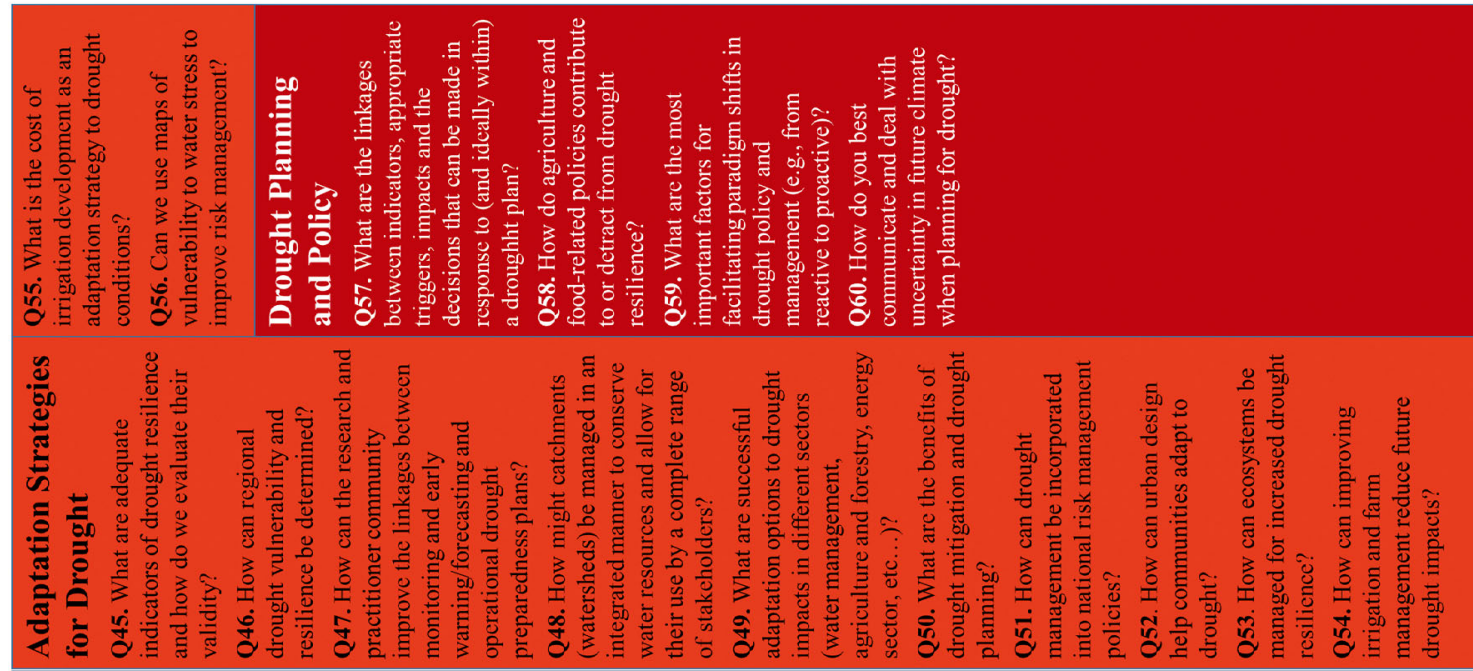

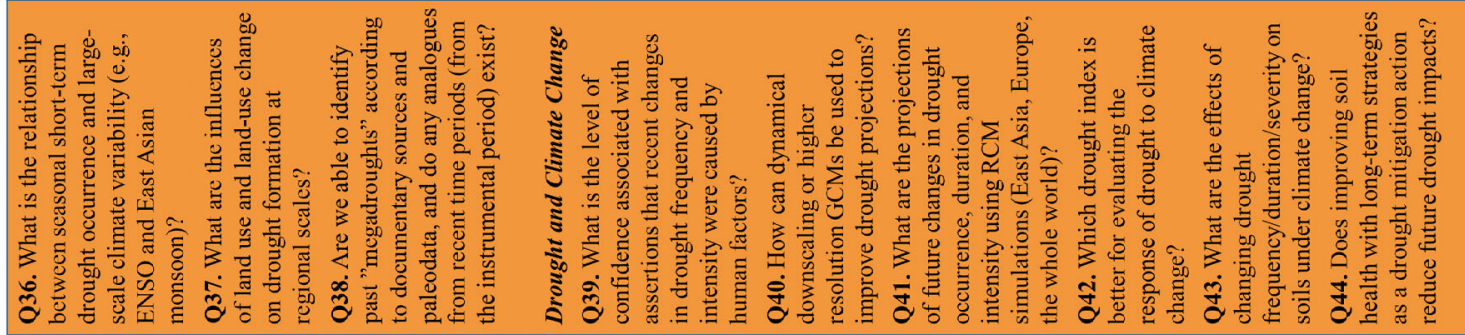

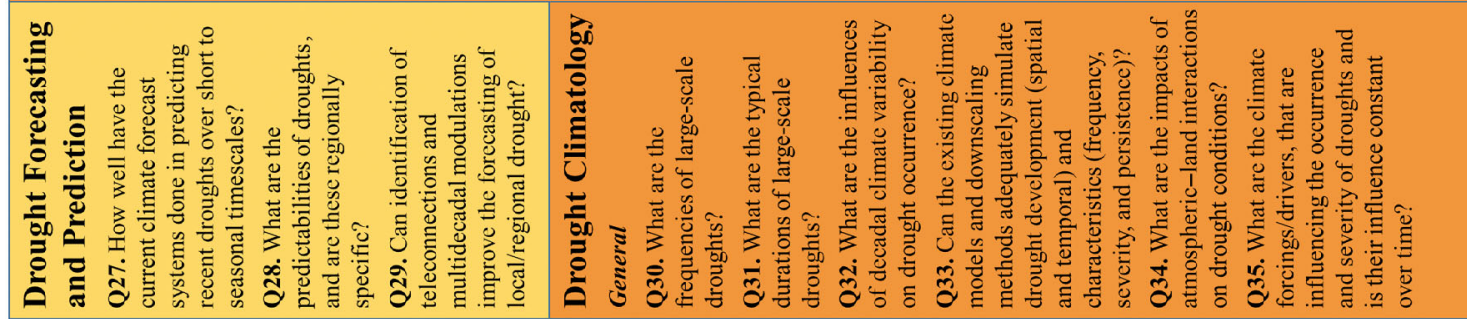

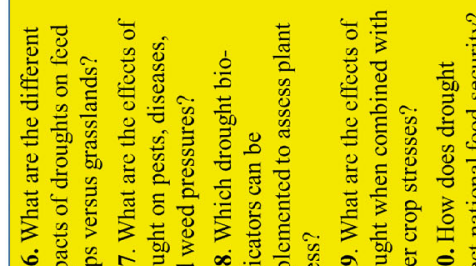

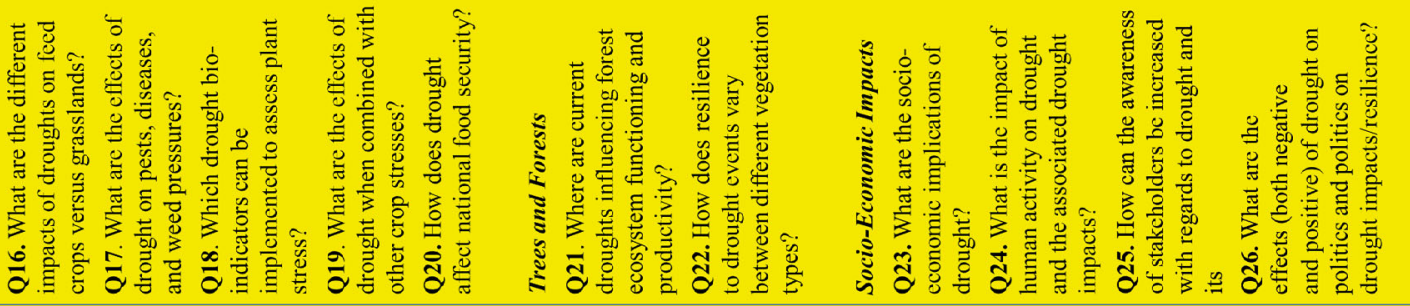

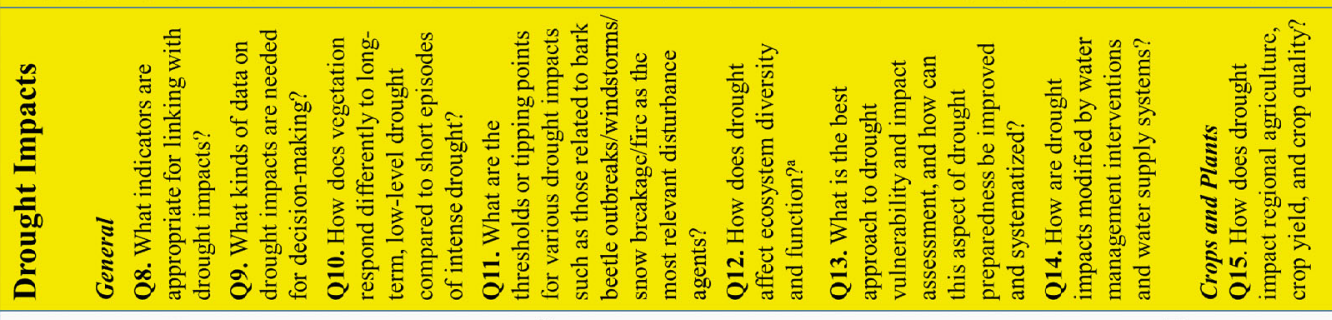

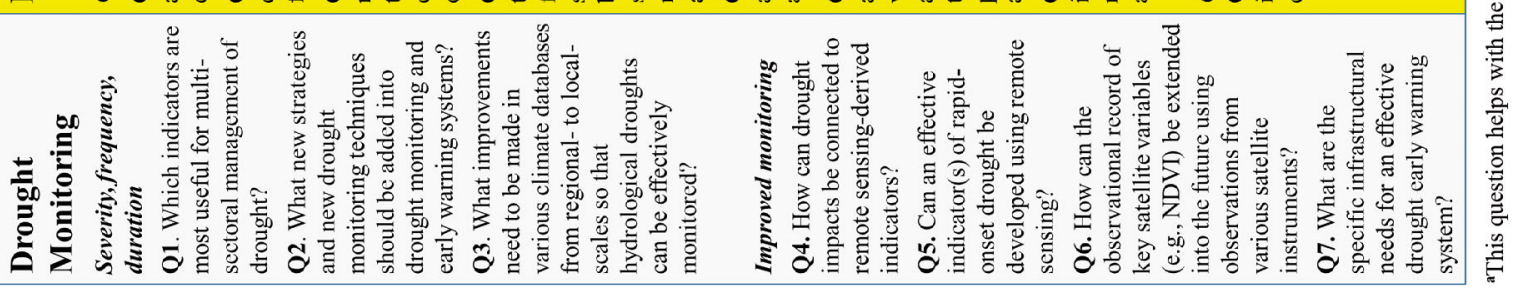


The development of new methods and their implementation to improve timely and effective decision making are also needed [Q2]. Additionally, new observation networks and technologies are needed to provide fresh information (e.g. Martínez-Fernández et al. 2016, Sánchez et al. 2016) for drought indices used in drought monitoring and management. Although numerous climate drought indices exist, the use of this information for hydrological drought monitoring in existing drought monitoring systems is usually non-direct and involves a separate set of indices (e.g. streamflow or snow pack data). The propagation of climatic droughts throughout the hydrological cycle is complex and depends on several factors, including lithology, water consumption, and water regulation (López-Moreno et al. 2009, Barker et al. 2016), among other factors, which makes it necessary to focus on the development of hydrological drought indices. An excellent example is the water status index developed for drought monitoring at the basin scale in Spain (Andreu et al. 2015), illustrating the potential for developing hydrological drought indices [Q3].

Drought monitoring based on Earth observation data has advanced since the 1980s, when the first high temporal resolution satellite imagery became available. Drought monitoring applications using remote sensing technologies evolve rapidly (Hayes et al. 2012), leading to products such as new soil moisture estimations (Sánchez et al. 2016). Here, the critical question of connecting remote sensing-derived drought monitoring to impacts resonates in [Q4], while the search for an early identification of drought onset is the focus of [Q5]. Currently, satellite data time series used for drought monitoring (e.g. that of the Advanced Very High Resolution Radiometer) span more than 2 decades. As satellite technologies improve, challenges associated with data continuity arise since newer sensors often have spatial, temporal, and radiometric characteristics that are inconsistent with those of earlier sensors. Research into transitioning between technologies involved in constructing long-term satellite records remains a high priority [Q6]. Equally important is the development of spatial fusion techniques that can be used to achieve high spatial resolutions (e.g. as shown in Fig. 3). However, this merged information is not yet ready for operational use in drought monitoring.

As a new generation of satellites with a multitude of more accurate and higher-resolution sensors (e.g. hyperspectral or microwave radar) becomes available, the development of associated infrastructure (e.g. to address the sheer volume of data and calculation time) is important [Q7] to many respondents.

\subsection{Impacts}

Although droughts often have a large spatial extent and affect many regions and sectors, the hardships caused by drought are local and primarily defined by the impacts on a local region and sector. Therefore, considerable attention is paid to addressing the question of drought impacts and the building of drought impact archives (e.g. Wilhite et al. 2007, Stahl et al. 2012, 2016, Blauhut et al. 2016). Linking particular drought indicators with drought impacts is considered a critical question [Q8] that needs to be better addressed, and one aspect of the question is whether a single indicator should be used to estimate various types of impacts or whether different drought indices are necessary to identify drought impacts in different sectors and territories. As a representative example, different studies have used the standardized precipitation evapotranspiration index (SPEI) (Vicente-Serrano et al. 2010) to estimate the impacts on crop yields (e.g. Potopová et al. 2015, Wang et al. 2016), hydrological drought (e.g. López-Moreno et al. 2013, Barker et al. 2016), forest growth decline (Camarero et al. 2013), desertification processes (Vicente-Serrano et al. 2012b), or even multiple sectors at once (e.g. VicenteSerrano et al. 2011a, Blauhut et al. 2016). However, the SPEI is not typically produced at local spatial scales. Even more importantly, identifying the most relevant impact data is critical for effective decision making [Q9]. Drought is a multifaceted extreme event with various durations. For instance, events can last a season, several years, or several decades, whereas socalled 'flash droughts' are much shorter (Hunt et al. 2014). The time dimension needs to be considered when drought impacts are assessed [Q10] and combined with proper knowledge of the 'tipping' points of specific societies and ecosystems (Fernald et al. 2015, Reyer et al. 2015, Huang et al. 2016) [Q11]. The cumulative drought impact is a function of not only the drought intensity and duration but also the ecosystem resilience and vulnerability, which need to be better understood [Q12-13] since the response of natural vegetation to drought is varied both in terms of resistance (Vicente-Serrano et al. 2013, Ivits et al. 2016) and resilience (Gazol et al. 2017). The impact of human activity on drought occurrence and impacts is particularly obvious in the area of water management, in which the frequency and patterns of drought are purposefully modified to suit human needs (e.g. Fig. 4) [Q14].

Agriculture and forestry have known sensitivities to drought both globally (e.g. Lesk et al. 2016) and regionally (e.g. in 2012) (Rippey 2015), and there is more to learn [Q15], including differences in drought 

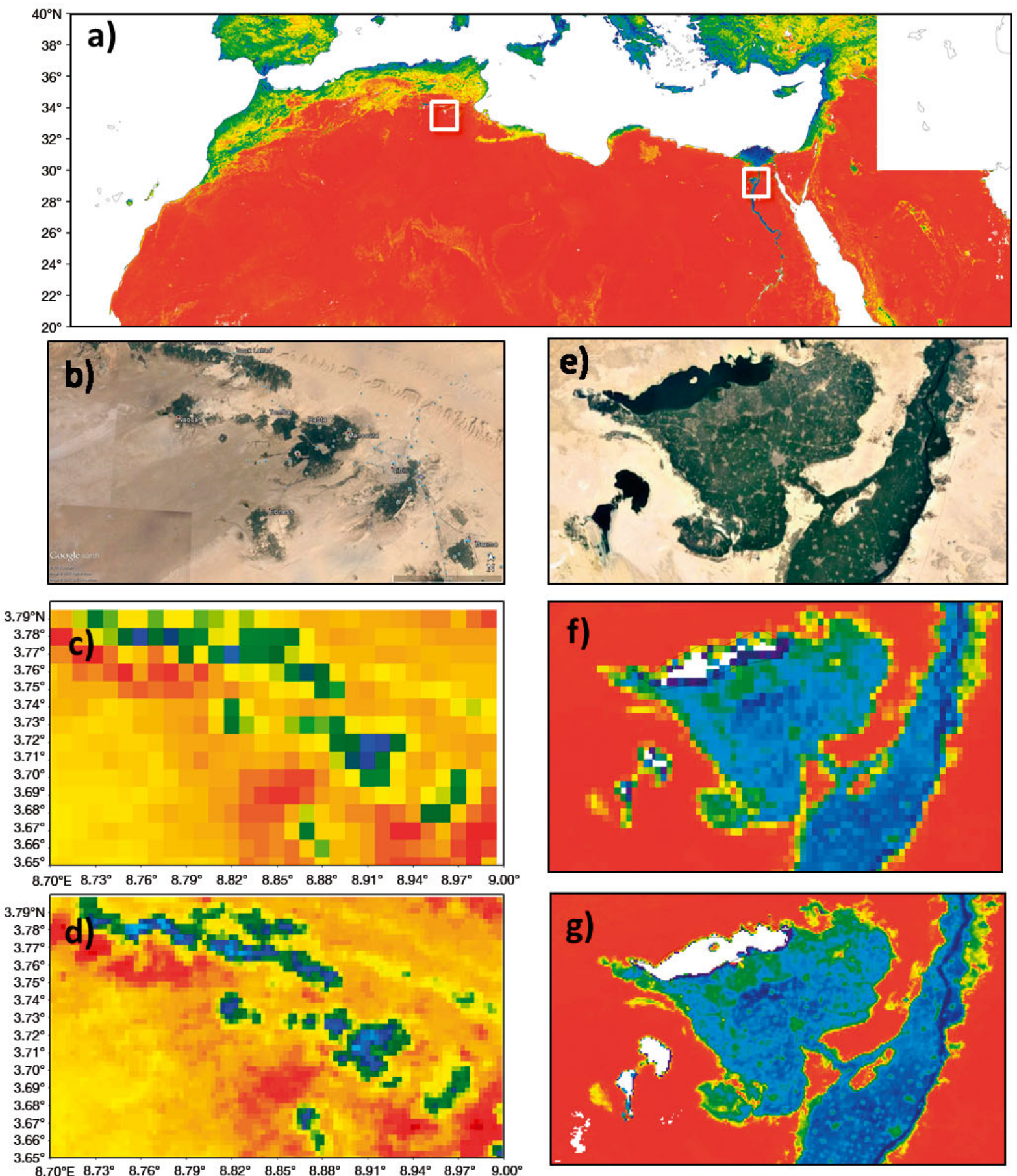

$\begin{array}{ccccccc}0 & 200 & 400 & 600 & 800 & 1000 & 1200\end{array}$

Fig. 3. (a) Examples of changing annual actual evapotranspiration (ET) based on different sensor characteristics and impacts on drought monitoring in northern Africa. White area (top-right) was not processed. The left white square represents pilot area: the Chott el Djerit basin in Tunisia depicted in detail at (b)-(d); the right white square shows the ancient Fajum Oasis (Egypt) depicted in detail at $(e)-(g)$; the VIIRS sensor $(d, g)$ is the successor to MODIS $(c, f)$ and provides significantly higher spatial resolution in the thermal band used for mapping water use and crop stress. However, it is difficult to effectively exploit this higher resolution in anomaly products given that the baseline (normal) conditions must be determined from the lowerresolution MODIS data. Images in (b,e) from Google Earth 


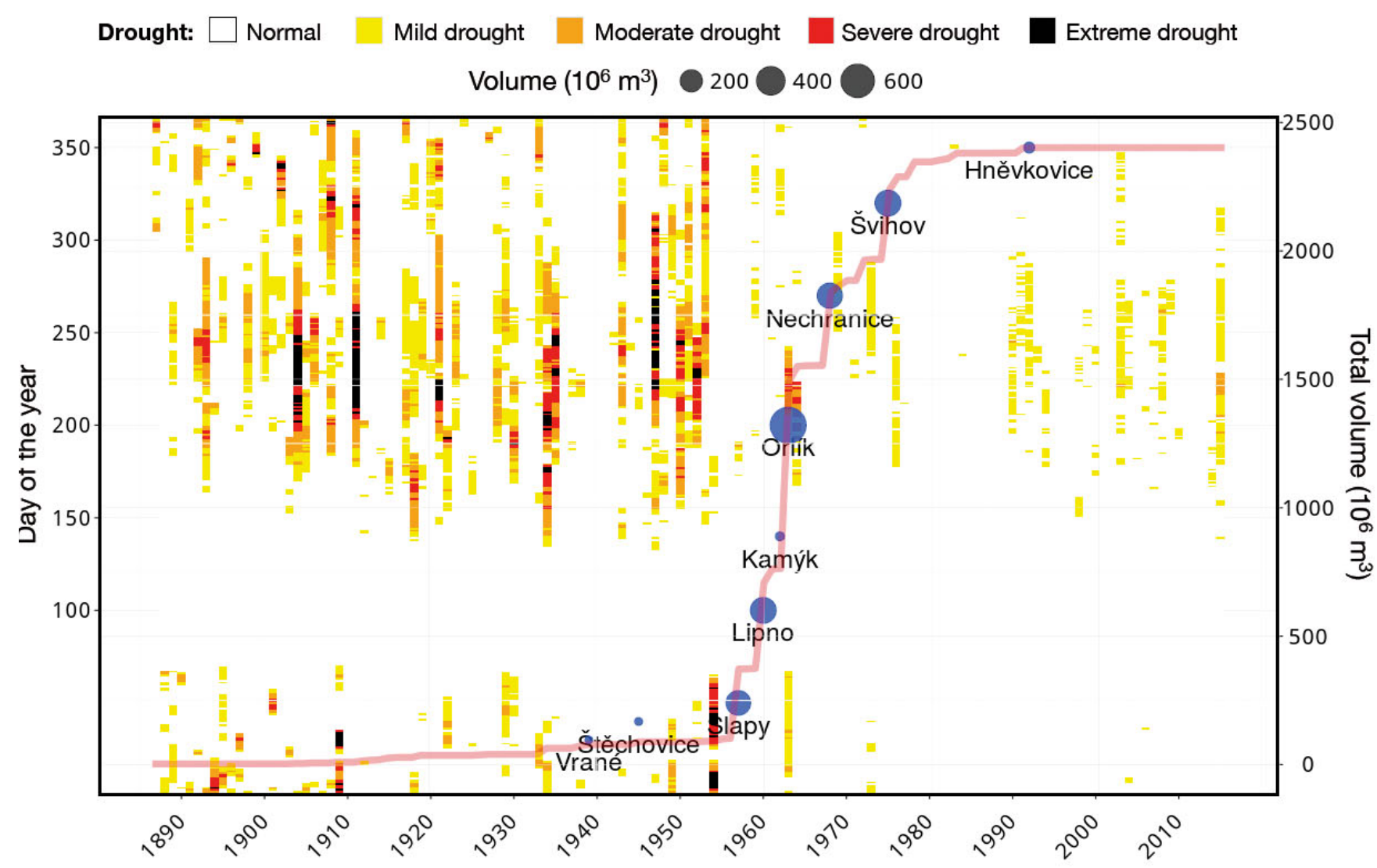

Fig. 4. Chronology of hydrological drought on the River Elbe at the Děčín station over the period 1888-2015, arranged with respect to various thresholds of daily discharge (above). A clear drop in drought frequency is apparent after 1950, when major upstream damming projects were completed. Blue spots represent the relative size of the reservoirs, and the pink line indicates the total volume dammed within the Elbe River catchment. An overview of the catchment with the location of the dams is shown on the right

sensitivity related to agriculture type [Q16]. The drought-yield relationship is modulated by a number of factors, including the pests, diseases or weed pressure [Q17], and need exists to separate drought from other influencing factors [Q18] and to understand feedbacks between drought and other adverse factors negatively affecting crops [Q19]. The combined effects of drought and warming are known to reduce

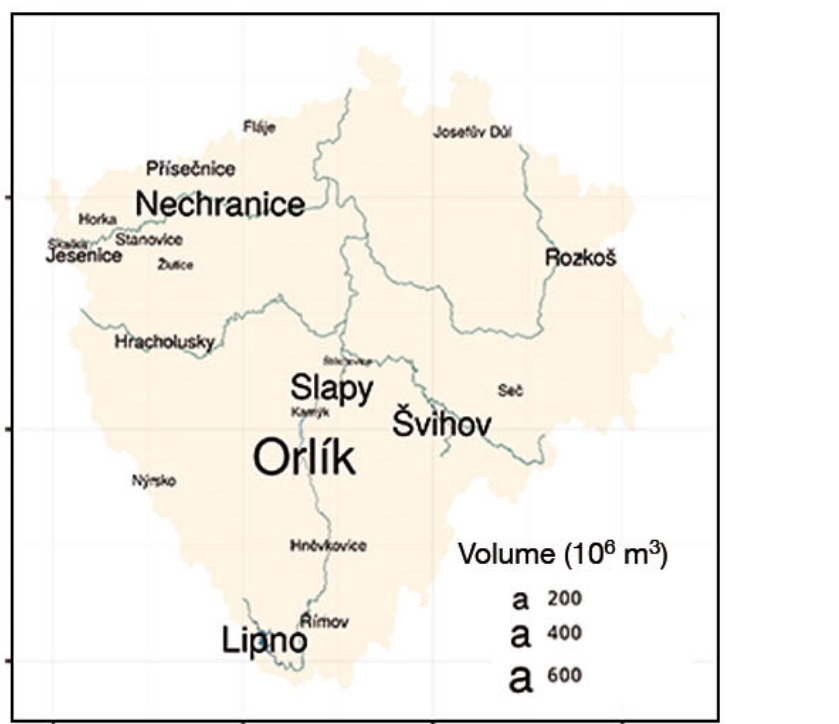

global crop production (Lobell et al. 2013, 2014). The close relationship between drought and other confounding factors is illustrated in Fig. 5, which shows a marked increase in the sensitivity of wheat to high temperatures during anthesis under drought conditions (K. Klem et al. pers. comm.). This relationship is important given the projected increase in drought occurrence/intensity under projected future climate 


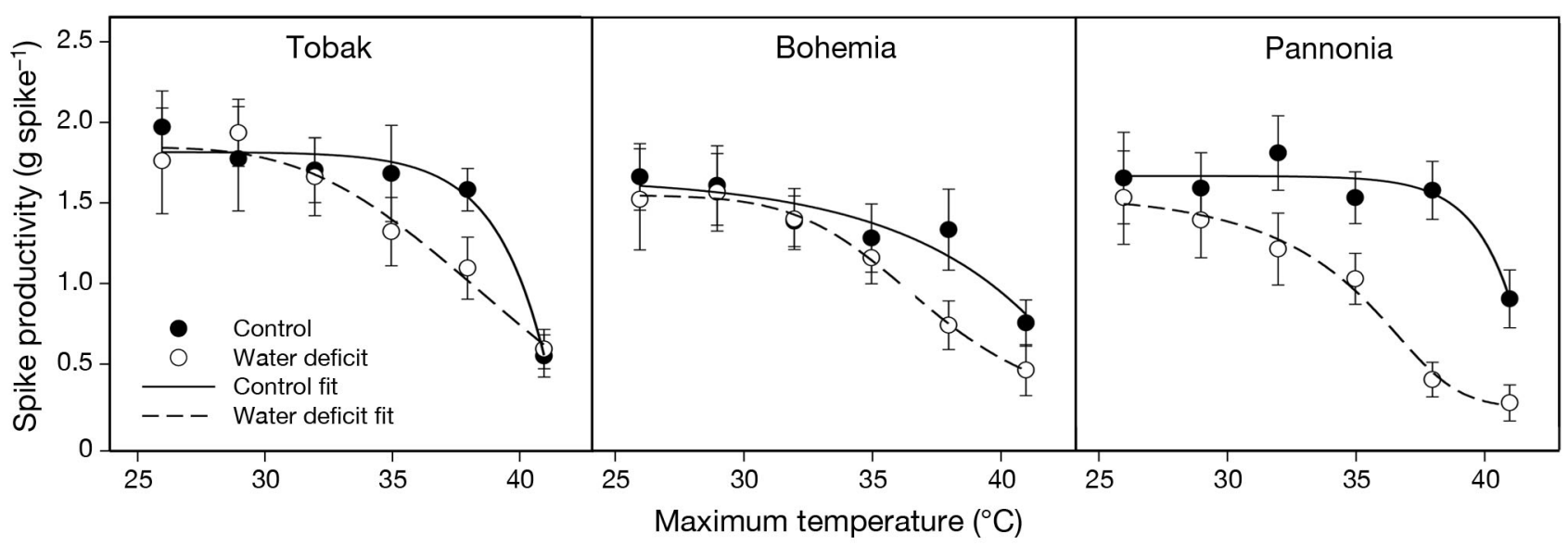

Fig. 5. Compiled results of recent growth chamber experiments showing the amplifying effect of drought on the wheat spike weight and demonstrating the crucial role of drought in wheat sensitivity to heat stress during anthesis. The significant difference in the response among the 3 cultivars ('Tobak,' 'Bohemia,' and 'Pannonia') indicates that varying coping strategies for different adaptations should be taken into account

conditions (e.g. Dai 2013, Feng et al. 2017). Drought has affected global food production over the past decade (e.g. Lobell et al. 2011), and the link between drought and food security ranks high among the priority questions [Q20].

In addition to the provisioning of food, the ecosystem services provided by forest ecosystems and forest productivity need to be addressed [Q21], as large uncertainties are associated with future forest growth in climate scenarios characterized by more severe and more frequent drought events (Williams et al. 2013). Therefore, the knowledge of factors that determine forest resilience to drought should be deepened [Q22] because large differences exist at the global scale (Anderegg et al. 2015, Gazol et al. 2017).

Understanding and quantifying the socio-economic impacts of drought remain challenging. Therefore, the Integrated Drought Management Program has begun investigating the benefits of action and the costs of inaction in addressing this challenge (WMO \& GWP 2017). The final set of questions within this thematic group relate to identifying the socioeconomic impacts in regions [Q23] and the relationships among these impacts and human activity and decision making [Q24]. Question [Q25] illustrates the challenge of enhancing stakeholder awareness to the different characteristics of droughts compared to other natural hazards. Understanding the linkages between drought impacts and policies was identified as an important question [Q26]. While the concept of drought impact propagation through the individual sectors has been discussed by various authors (e.g. Fig. 6a), further research is needed to understand all of the indirect effects that can result (Ding et al. 2011). A clear need also exists for quantitative studies that mine the available datasets and test existing concepts such as a recent study on seemingly unrelated mental health consequences of drought (Fig. 6b) (Vins et al. 2015).

\subsection{Forecasting}

While monitoring droughts and drought impacts are critical for efficient drought response [Q27], forecasting and prediction are key for any drought early warning system. Improved forecasting and prediction can assist the timely implementation of drought plans and provide information for targeting drought relief efforts (e.g. Enenkel et al. 2015) or improved farming (e.g. Tadesse et al. 2016). Early warning systems have been implemented in most developed economies (e.g. the National Integrated Drought Information System program in the US) in an effort to reduce costly damage. The forecast and prediction efforts take various forms, ranging from long-term forecasts (Fig. 7a: US drought outlook), through medium-term (Tadesse et al. 2010), to short-term high-resolution forecasts considering ensembles of numerical weather prediction models (Fig. 7b: InterDrought - 5 model maps).

Although the relationships between oceanic indices (e.g. El Niño-Southern Oscillation [ENSO] and the North Atlantic Oscillation) and droughts are reasonably well understood, the use of these indices to predict drought requires further research [Q28]. Advancing knowledge of the atmospheric mechanisms 

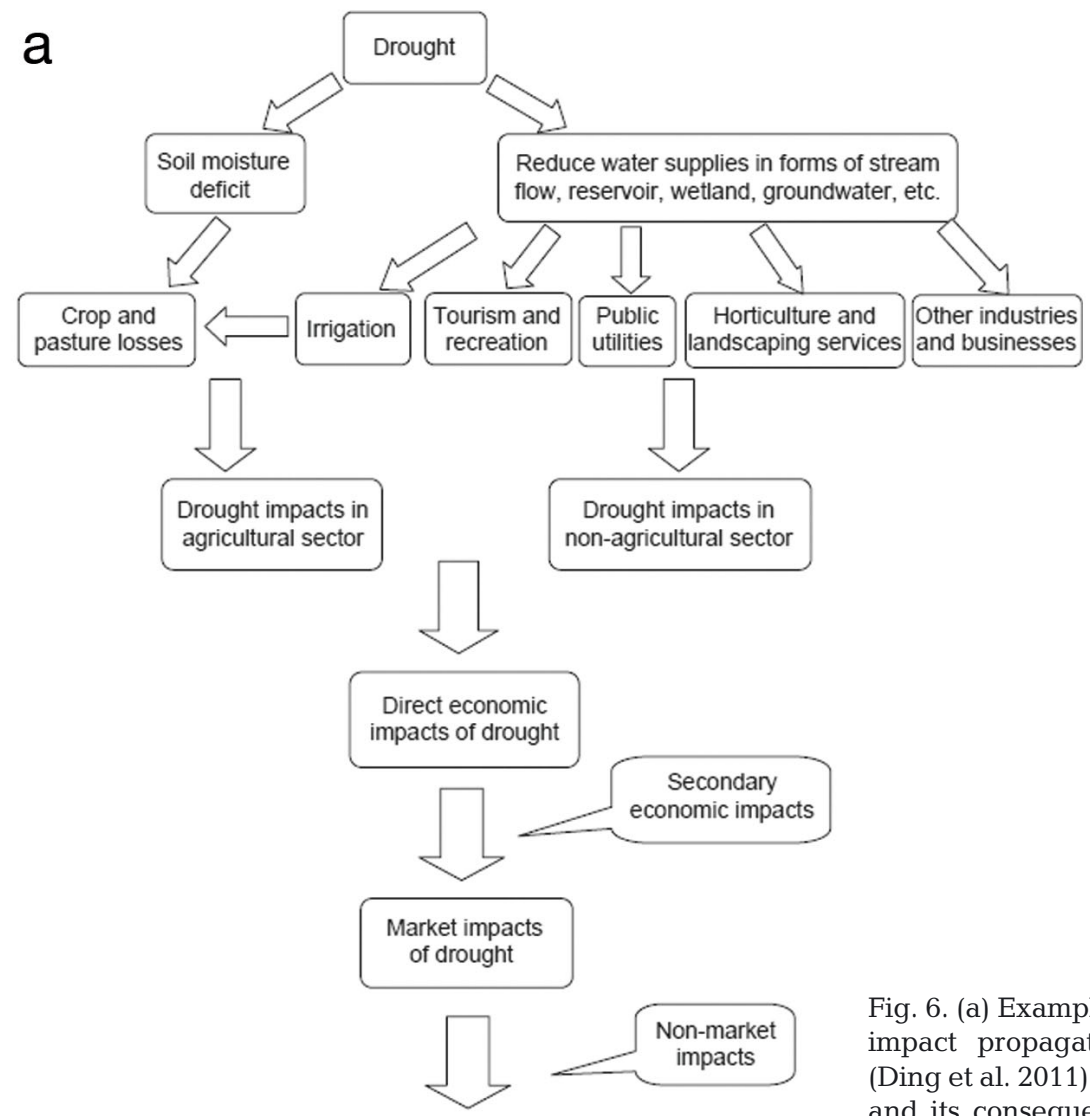

Fig. 6. (a) Example of conceptualized drought impact propagation through the economy (Ding et al. 2011) and (b) pathways of drought and its consequences (black and black) impacting the mental health and behaviour (red) of the population in a drought-affected area

(Vins et al. 2015)

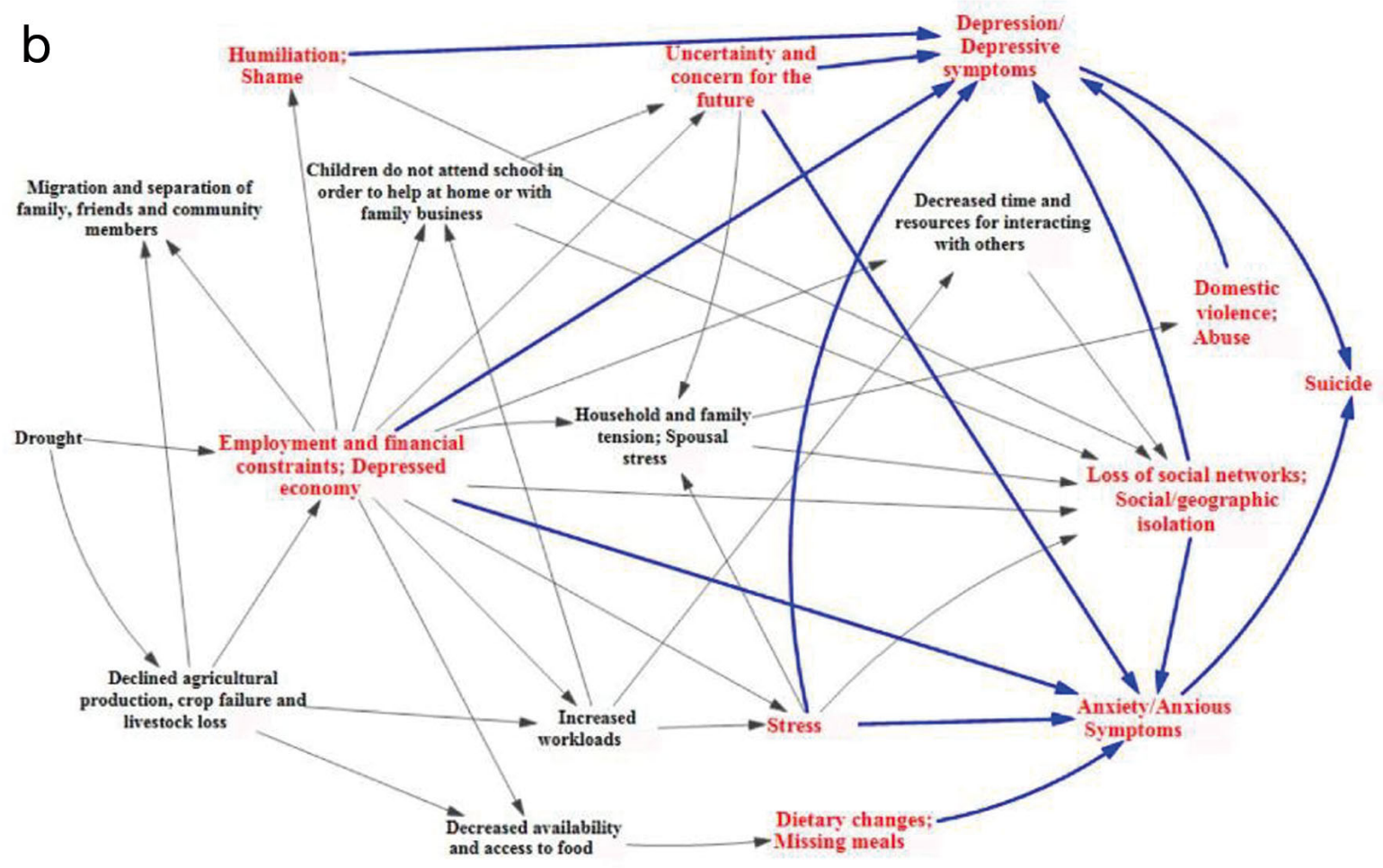




\section{U.S. Seasonal Drought Outlook valid for September 15 - December 31, 2016 Drought Tendency During the Valid Period
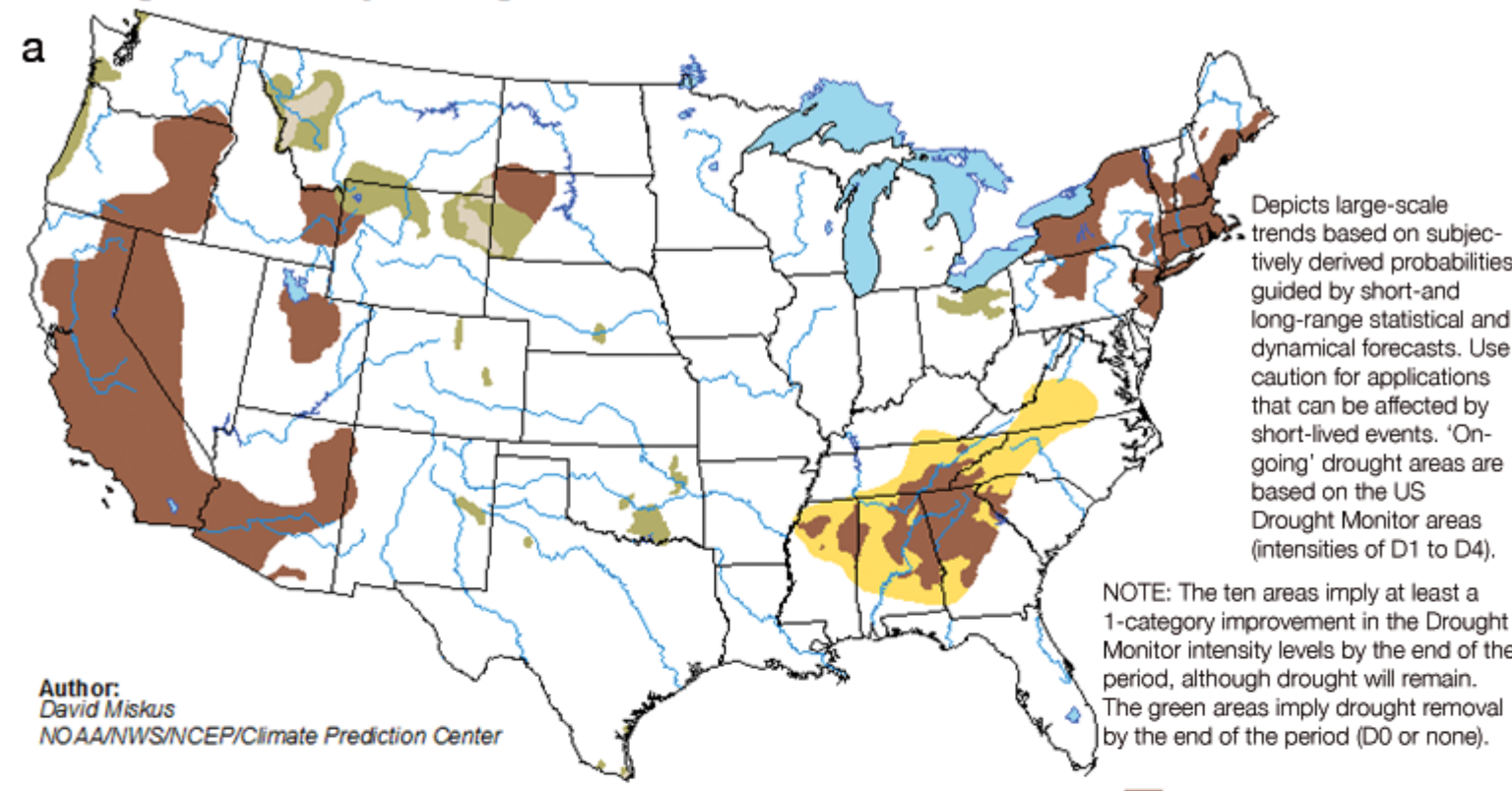

NOTE: The ten areas imply at least a 1-category improvement in the Drought Monitor intensity levels by the end of the period, although drought will remain.

The green areas imply drought removal by the end of the period (DO or none).
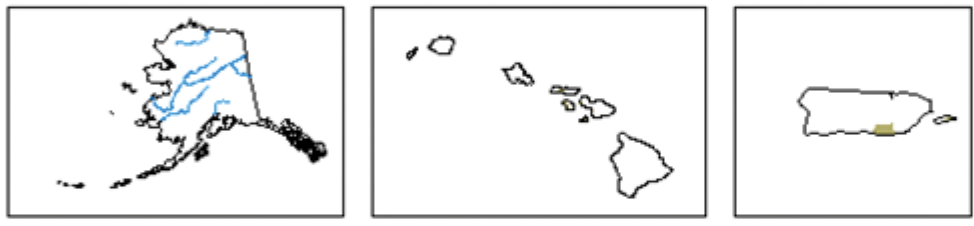

Drought persists

Drought remains but improves

Drought removal likely

Drought development likely

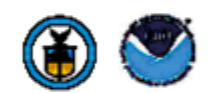

http://go.usa.gov/3eZ73

b 9-DAY FORECAST - 5 Numerical Weather Prediction Models Overview Issued: July 5, 2017 Part: 1/3

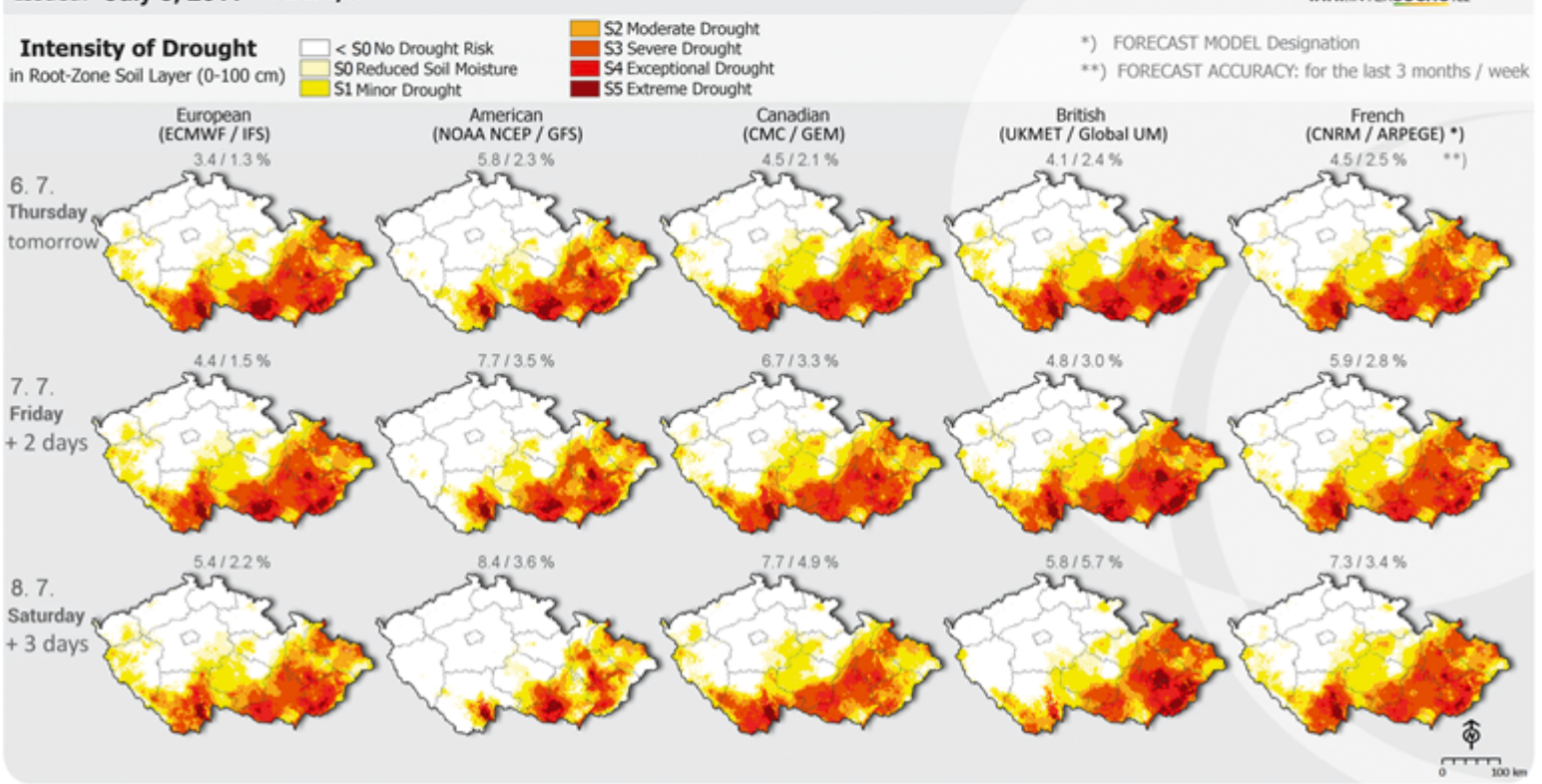

Fig. 7. (a) Example of a long-term 'continental-scale' drought forecast for the USA in comparison with (b) a high-resolution $(500 \times 500 \mathrm{~m})$ short-term forecast using the ensemble of 5 numerical weather prediction models for the Czech Republic where forecast error (\%) is also given for each 
that control drought variability and severity could improve drought forecasting skill [Q29]. ENSO is one of the main drivers of climate variability at the global scale, and large areas of the world show a strong drought severity response to these events (Dai et al. 1998, Dai 2011, Vicente-Serrano et al. 2011a).

\subsection{Climatology}

Large-scale drought events affecting significant portions of a continent, such as the 2010 drought in Russia or the 2012 drought across the central US, highlight the need for enhanced preparedness for future droughts in terms of frequency [Q30], duration, extent, and termination [Q31] (Parry et al. 2016a,b). The recent drought in California (e.g. Seager et al. 2014) demonstrates that even advanced economies are vulnerable to long-term drought, because such events have multiple cascading societal consequences that are difficult to predict. In some regions of the world, drought occurrence has been linked to long-term temporal variability patterns, such as the Atlantic and Pacific multi-decadal oscillations (McCabe et al. 2004, Mohino et al. 2011, Oglesby et al. 2012). Therefore, being able to derive linkages between decadal climate variability and the occurrence of drought [Q32] and properly model drought [Q33] are needed to improve forecasts. Understanding the underlying physical processes requires an understanding of the influence of landatmosphere interactions ([Q34], Lejeune et al. 2017). Climate forcings/drivers or large-scale climate phenomena (e.g. El Niño) need to be studied [Q35-36] for the same reason because they provide hints about the long-term predictability of drought risk (e.g. Nicolai-Shaw et al. 2016) or allow attribution of drought trends to particular forcings (Brázdil et al. 2015, Gudmundsson \& Seneviratne 2016). Some examples (e.g. Davidson et al. 2012) urge researchers to decipher the relationships between drought formation and land-use changes [Q37]. On longer time scales, some researchers are concerned about 'megadrought' events, such as the medieval 'megadroughts' in the western US (Cook et al. 2004, 2007), and shorter but still extreme events, such as the 1540 drought in Europe (Wetter et al. 2014). A 12-centurylong perspective of Northern Hemisphere hydroclimate anomalies was recently provided by Ljungqvist et al. (2016) (Fig. 8). Although this study did not focus on 'mega-droughts,' such large-scale studies (in terms of both area and time covered) are critical for our understanding of the potential for extraordinary events [Q38], the long-term variation in large-scale drought probability, and the drivers responsible for these events. Understanding drought teleconnections and past drought frequencies is also critical for supporting reported increases in the drought frequency/severity in some regions (e.g. Trnka et al. 2009, 2015, Vicente-Serrano et al. 2014) that have been attributed to climate changes [Q38]. Although some studies (e.g. Trigo et al. 2013, Brázdil et al. 2015) have provided fairly conclusive evidence that increases in drought frequency are linked to increasing $\mathrm{CO}_{2}$ and no other known factor, this relationship remains to be quantified globally in a comprehensive way [Q39].

Assessing future changes in drought frequency and severity either via new methods of downscaling or higher-resolution global circulation models [Q40] and/or regional climate models [Q41] is also high on the agenda. The development of a new generation of climate models is considered especially important. In recent years, we have witnessed several debates (e.g. Dai 2011, Vicente-Serrano et al. 2011b, 2015, Hoerling et al. 2012, Beguería et al. 2014, Feng et al. 2017) centered around choosing the most appropriate drought index for assessing drought under changing climate conditions; the associated inconsistencies should be clarified [Q42]. Additionally, the drought risks associated with climate change caused by future carbon emissions should be quantified [Q43]. Moreover, the frequently recommended concept of improving soil health as a drought mitigation strategy remains to be objectively tested [Q44].

\subsection{Adaptation}

Acquiring the capability to enhance long-term drought resilience is a critical part of risk management strategies, as shown by the development of the National Integrated Drought Information System in the US. To promote risk management and to increase resilience, adequate indicators should be used, and their validity should be assessed [Q45]. Increasing local resilience requires a methodological framework to determine vulnerability and resilience [Q46]. Drought plans are viewed as an aspect of enhancing drought resilience (Wilhite et al. 2005). However, in the regions/countries where drought planning and drought monitoring are divided (e.g. between different ministries or governmental levels), the linkages between these 2 critical components of the drought response system should be improved [Q47]. It remains to be seen how much of eventual conflicts might be re- 

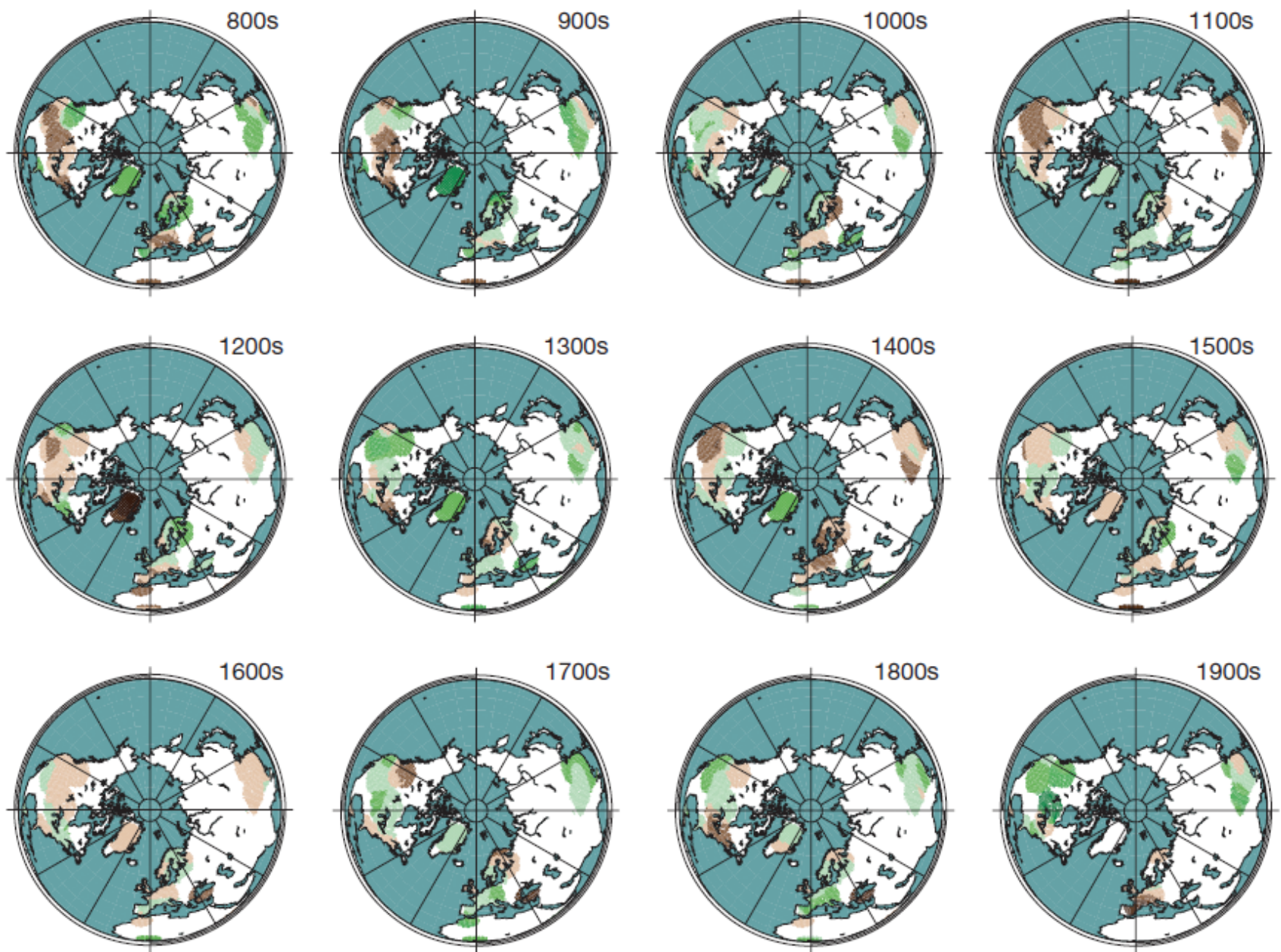

Fig. 8. Spatio-temporal distribution of gridded centennial hydrological proxy anomalies (brown: drought, green: wet) over land areas with at least 3 independent proxies within the estimated centennial correlation decay length for centennial-scale hydrological variability. Anomalies are shown relative to the centennial mean and standard deviation over the $11^{\text {th }}$ to the $19^{\text {th }}$ centuries. The color scale is truncated at -2 and 2 , and areas with insufficient proxy coverage to compute a gridded weighted mean value are left white. From Fig. 2a in Ljungqvist et al. (2016)

solved through the integrated use of resources [Q48], and more research is required to identify and rank the available adaptation options [Q49]. The benefits of drought mitigation and drought planning seem to be obvious and have been listed by some researchers, such as Schwab (2013); however, more quantitative assessments are needed in order to demonstrate these benefits and provide officials with the support to take proactive actions. Studies focused on costbenefit analysis of drought planning and drought mitigation would be highly beneficial when framing public discussion [Q50], as conceptual models (Fig. 9) need to be supported by data.

The proper and functional inclusion of drought into overall risk management policies remains a challenge that needs to be tackled [Q51]. As the overall regional drought resilience can be viewed as a product of the resilience of individual sectors and landscape compo- nents, studying and improving the resilience of these factors should also be prioritized [Q52-56]. These sectors/landscape components include urban areas [Q52], managed and non-managed ecosystems [Q53],

\begin{tabular}{|c|c|c|}
\hline $\begin{array}{c}\text { Costs of Inaction } \\
\text { (includes costs of: ) }\end{array}$ & \multicolumn{2}{|c|}{$\begin{array}{c}\text { Costs of Action } \\
\text { (includes costs of: ) }\end{array}$} \\
\hline & Crisis management & $\begin{array}{c}\text { Preparedness and risk } \\
\text { management }\end{array}$ \\
\hline & \multirow{3}{*}{$\begin{array}{l}\text { - Drought } \\
\text { impacts } \\
\text { (substantial) } \\
\text { - Relief } \\
\text { actions } \\
\text { (high) }\end{array}$} & \multirow{3}{*}{$\begin{array}{l}\text { - Drought impacts } \\
\text { (low) } \\
\text { - Relief actions } \\
\text { (low) } \\
\text { - Preparedness } \\
\text { actions } \\
\text { - Risk mitigation } \\
\text { actions }\end{array}$} \\
\hline $\begin{array}{l}\text { - Drought impacts } \\
\text { (high) }\end{array}$ & & \\
\hline & & \\
\hline
\end{tabular}

Fig. 9. Conceptual model illustrating the diminishing consequences, moving from left to right, of inaction to drought, drought response with a crisis management approach, and an approach that promotes preparedness and risk management (adapted from WMO \& GWP 2017) 
and farmland [Q54-56], where irrigation and its associated costs are considered important research questions (e.g. Rey et al. 2017).

\subsection{Planning and policy}

Planning for drought events is intertwined with drought monitoring, forecasting, and impact assessment; thus, finding the proper relationship among these themes is paramount in drought planning [Q57]. Some studies (e.g. Blauhut et al. 2016) indicate that finding critical thresholds is difficult and requires substantial and widespread analysis of data archives and innovative statistical techniques. In some cases, specific policies might affect drought resilience in undesirable ways (e.g. limiting drought resilience by primarily focusing on drought impact alleviation) [Q58]. The development of and changes in drought policy are usually initiated by a major drought episode, as in 1947 in Central Europe (e.g. Brázdil et al. 2016) or in the late 1990s in the US Midwest (e.g. McLeman et al. 2014). Understanding why some drought events trigger responses at the policy level seemed critical to the respondents [Q59]. The final research question reflects one of the major challenges associated with preparing meaningful longterm drought policy, i.e. ongoing climate change and uncertainty in the magnitude (and in some regions also the sign) of the change [Q60].

\section{CONCLUSIONS}

This study drew its inspiration from other priority research exercises that have taken place in fields such as ecology (Sutherland et al. 2013), paleoecology (Seddon et al. 2014), and historical ecology (Armstrong et al. 2017). As noted in the preceding exercises, the resulting drought questions are in no way final and definitive. The 431 initial questions were a heterogeneous mix of general and specific questions, and the subsequent 4 -phase process generated increasingly universal questions. For example, approximately 30 region-specific questions were translated into several more general questions that are, in our view, more relevant to a wider global audience. In the current structure, the 60 questions may be adapted to various regions of the world and can also serve as a 'check-list' in formulating drought research priorities, starting with identifying appropriate monitoring methods [Q1-7] and drought impact assessment strategies [Q8-26], forecasting drought and understanding drought climatology [Q27-38], and addressing climate change consequences [Q39-44]. While the first two-thirds of the questions represent basic research on drought as a natural science phenomenon, a significant share of the questions cover the societal components of drought. These questions [Q45-60] are more in the realm of applied research, and include adaptation strategies for drought and the planning and policy aspects of the issue. In general, method-oriented questions represent relatively large proportions of the 'Adaptation strategies to drought' theme and the themes dealing with drought monitoring and impact assessment. This pattern is understandable because, while there has been marked development in drought monitoring and assessment tools, much work remains to be done at the science-decision making interface.

While the process of question evaluation was based on robust and tested methodology, the final list of 60 priority research questions is skewed towards those where common agreement could be found. On the other hand, 'provocative' or 'original' questions that drew highly contrasting views, or appealed to a small subset of the participants, naturally fell down in the list due to the question ranking process (e.g. Fig. 2b). For this reason, readers are advised to use Supplement 4 to explore the research questions that did not pass the final 'cut' in which only the most 'consensual' questions were retained. Supplement 3 provides readers with the view of the original set of questions including those that were narrowly focused on a particular region/research field, and thus tended to score lower in the evaluation process.

The formulated questions also show that the criteria selected to define drought must be stated explicitly (Wilhite \& Glantz 1985) so that the definition can be evaluated and its applicability to other locations examined (e.g. Lloyd-Hughes 2014 or [Q8]). On the other hand, some of the concluding questions (e.g. [Q59] and [Q60]) indicate difficulty on the part of the research community in reaching out to decision makers, particularly those at the policy levels, to highlight the importance of drought, which was also identified as one of the major research issues 3 decades ago (Wilhite \& Glantz 1985).

Despite the continued efforts to understand how drought is defined for different sectors and across various regions, the list does highlight the massive technological advances in the area of remote sensing and ground-based monitoring of drought onset, severity, and impacts. Never in the past have researchers been in the position (at least potentially) to monitor the climate, land use, and societal drivers of drought and 
drought impacts globally, and at such a high resolution and in near real time. At the same time, the wealth of information on drought variability and impacts over previous centuries to study drought-society interactions has been growing in response to networking and international collaborations. In a way, the set of questions presented by this paper reflects the challenges of such situations, with many researchers feeling that the commonly used approaches are not enough to utilize new information, and that substantial human and computational resources should be devoted to making sense of the available data. We are proposing 3 steps that would, in our view, greatly speed up the process of answering many of the posed questions:

(1) Organize global inter-comparison and improvement projects focused on available methods in the monitoring and forecasting of drought and drought impacts, fostering collaboration among all research labs across continents and disciplines using the experiences of similar efforts in related research fields (e.g. AgMIP project - www.agmip.org/);

(2) Create a multiscale, open-access repository of both ground and remote sensing based drought indicators as well as drought impacts that would be properly documented and updated;

(3) Commission review and position papers as collaborative efforts to leading research labs that would capture the present state-of-the-art, particularly in the fields of drought monitoring (including both ground based and remote sensing), drought impacts, drought forecasting and prediction, drought adaptation strategies, and drought planning and policy.

The list of 60 questions expresses, to a large extent, the interdisciplinarity and the multiple settings of drought research, and it maps at least some of the knowledge gaps that still exist or are perceived to exist. In the case of drought research, the link with stakeholders (and frequently the main funders) should be as close as possible, and the research should directly affect existing policies and legislation. Therefore, closing the known knowledge gap is important, and this list of questions can be used as a guide to define research needs in particular regions/ sectors.

Acknowledgements. We acknowledge the collaboration of all researchers listed in Supplement 2, who either proposed drought research questions and/or contributed to their ranking. The study was supported by the Ministry of Educa- tion, Youth and Sports of the Czech Republic within the National Sustainability Program I (NPU I LO1415). M.T. and P.H. were additionally supported by the National Agency for Agricultural Research (project no. QJ1610072). R.B. was supported by the Czech Grant Agency project no. 17-10026S and P.D. by project no. GA 13-04291S. I.H. was supported by the UK Natural Environment Research Council (NE/L010070/1 and NE/L010186/1). Any use of trade, product, or firm names is for descriptive purposes only and does not imply endorsement by the US Government. We thank 2 anonymous reviewers for helpful comments that helped to improve the manuscript, particularly in relation to the conclusion formulation. We have no conflicts of interest to declare.

\section{LITERATURE CITED}

Allen CD, Macalady AK, Chenchouni H, Bachelet D and others (2010) A global overview of drought and heatinduced tree mortality reveals emerging climate change risks for forests. For Ecol Manag 259:660-684

*Anderegg WRL, Schwalm C, Biondi F, Camarero JJ and others (2015) Pervasive drought legacies in forest ecosystems and their implications for carbon cycle models. Science 349:528-532

Anderson DG, Maasch K, Sandweiss DH (eds) (2007) Climate change and cultural dynamics: a global perspective on mid-Holocene transitions. Academic Press, London

Andreu J, Solera A, Paredes-Arquiola J, Haro-Monteagudo D, van Lanen H (eds) (2015) Drought: research and science-policy interfacing. CRC Press/Taylor and Francis, Boca Raton, FL

Armstrong CG, Shoemaker AC, McKechnie I, Ekblom A and others (2017) Anthropological contributions to historical ecology: 50 questions, infinite prospects. PLOS ONE 12: e0171883

Bachmair S, Kohn I, Stahl K (2015) Exploring the link between drought indicators and impacts. Nat Hazards Earth Syst Sci 15:1381-1397

* Barker LJ, Hannaford J, Chiverton A, Svensson C (2016) From meteorological to hydrological drought using standardised indicators. Hydrol Earth Syst Sci 20:2483-2505

Barlow M (2012) Africa and west Asia. Intraseasonal variability of the atmosphere-ocean climate system, 2nd ed. Lau WKM, Waliser DE (eds) Springer-Verlag Berlin, p 477-496

Beguería S, Vicente-Serrano SM, Reig F, Latorre B (2014) Standardized precipitation evapotranspiration index (SPEI) revisited: parameter fitting, evapotranspiration models, tools, datasets and drought monitoring. Int $\mathrm{J}$ Climatol 34:3001-3023

Beniston M (2012) Impacts of climatic change on water and associated economic activities in the Swiss Alps. J Hydrol (Amst) 412-413:291-296

* Blauhut V, Stahl K, Stagge JH, Tallaksen LM, Stefano LD, Vogt J (2016) Estimating drought risk across Europe from reported drought impacts, drought indices, and vulnerability factors. Hydrol Earth Syst Sci 20:2779-2800

* Bocinsky RK, Kohler TA (2014) A 2000-year reconstruction of the rain-fed maize agricultural niche in the US Southwest. Nat Commun 5:5618

`Bázdil R, Dobrovolný P, Trnka M, Kotyza O and others (2013) Droughts in the Czech Lands, 1090-2012 AD. Clim Past 9:1985-2002

Brázdil R, Trnka M, Mikšovský J, Řezníčková L, Dobrovolný P 
(2015) Spring-summer droughts in the Czech Land in 1805-2012 and their forcings. Int J Climatol 35:1405-1421

Brázdil R, Raška P, Trnka M, Zahradníček P and others (2016) The Central European drought of 1947: causes and consequences, with particular reference to the Czech Lands. Clim Res 70:161-178

Breshears DD, Cobb NS, Rich PM, Price KP and others (2005) Regional vegetation die-off in response to globalchange-type drought. Proc Natl Acad Sci USA 102: 15144-15148

Buckley BM, Anchukaitis KJ, Penny D, Fletcher R and others (2010) Climate as a contributing factor in the demise of Angkor, Cambodia. Proc Natl Acad Sci USA 107: 6748-6752

Büntgen U, Trouet V, Frank D, Leuschner HH, Friedrichs D, Luterbacher J, Esper J (2010) A tree ring-based reconstruction of summer drought for Central Germany and the last millennium. Quat Sci Rev 29:1005-1016

Camarero J, Manzanedo R, Sanchez-Salguero R, NavarroCerrillo R (2013) Growth response to climate and drought change along an aridity gradient in the southernmost Pinus nigra relict forests. Ann For Sci 70: 769-780

* Camuffo D, Bertolin C, Barriendos M, Domínguez-Castro F and others (2010) 500-Year temperature reconstruction in the Mediterranean Basin by means of documentary data and instrumental observations. Clim Change 101: 169-199

Ciais P, Reichstein M, Viovy N, Granier A and others (2005) Europe-wide reduction in primary productivity caused by the heat and drought in 2003. Nature 437:529-533

* Cook BI, Smerdon JE, Seager R, Cook ER (2014) Pan-Continental droughts in North America over the last millennium. J Clim 27:383-397

* Cook ER, Meko DM, Stahle DW, Cleaveland MK (1999) Drought reconstructions for the continental United States. J Clim 12:1145-1162

Cook ER, Woodhouse CA, Eakin CM, Meko DM, Stahle DW (2004) Long-term aridity changes in the western United States. Science 306:1015-1018

* Cook ER, Seager R, Cane MA, Stahle DW (2007) North American drought: reconstructions, causes, and consequences. Earth Sci Rev 81:93-134

Cook ER, Anchukaitis KJ, Buckley BM, D'Arrigo RD, Jacoby GC, Wright WE (2010) Asian monsoon failure and megadrought during the last millennium. Science 328:486-489

* Cook ER, Seager R, Kushnir Y, Briffa KR and others (2015) Old World megadroughts and pluvials during the Common Era. Sci Adv 1:e1500561

CRED, UNISDR (Centre for Research on the Epidemiology of Disasters, UN Office for Disaster Risk Reduction) (2016) Poverty \& death: disaster mortality 1996-2015. http://cred.be/HCWRD (accessed 13 June 2017)

Dai A (2011) Drought under global warming: a review. Wiley Interdiscip Rev Clim Change 2:45-65

* Dai A (2013) Increasing drought under global warming in observations and models. Nature Clim Change 3:52-58

* Dai A, Trenberth KE, Karl TR (1998) Global variations in droughts and wet spells: 1900-1995. Geophys Res Lett 25: 3367-3370

Davidson EA, de Araújo AC, Artaxo P, Balch JK and others (2012) The Amazon basin in transition. Nature 481: 321-328

Davis M (2001) Late Victorian holocausts: El Niño famines and the making of the Third World. Verso, London
Ding D, Maibach EW, Zhao X, Roser-Renouf C, Leiserowitz A (2011) Support for climate policy and societal action are linked to perceptions about scientific agreement. Nat Clim Chang 1:462-465

* Domínguez-Castro F, Ribera P, García-Herrera R, Vaquero JM, Barriendos M, Cuadrat JM, Moreno JM (2012) Assessing extreme droughts in Spain during 1750-1850 from rogation ceremonies. Clim Past 8:705-722

* Douglas PMJ, Demarest AA, Brenner M, Canuto MA (2016) Impacts of climate change on the collapse of Lowland Maya Civilization. Annu Rev Earth Planet Sci 44:613-645

* Enenkel M, See L, Karner M, Álvarez M and others (2015) Food security monitoring via mobile data collection and remote sensing: results from the Central African Republic. PLOS ONE 10:e0142030

* Esper J, Frank DC, Büntgen U, Verstege A, Luterbacher J, Xoplaki E (2007) Long-term drought severity variations in Morocco. Geophys Res Lett 34:L17702

Feng S, Trnka M, Hayes M, Zhang Y (2017) Why do different drought indices show distinct future drought risk outcomes in the U.S. Great Plains? J Clim 30:265-278

* Fernald A, Guldan S, Boykin K, Cibils A and others (2015) Linked hydrologic and social systems that support resilience of traditional irrigation communities. Hydrol Earth Syst Sci 19:293-307

Fleig AK, Tallaksen LM, Hisdal H, Demuth S (2006) A global evaluation of streamflow drought characteristics. Hydrol Earth Syst Sci 10:535-552

García-Herrera R, Hernández E, Barriopedro D, Paredes D, Trigo RM, Trigo I, Mendes MA (2007) The outstanding 2004/05 drought in the Iberian Peninsula: associated atmospheric circulation. J Hydrometeorol 8:483-498

*Gazol A, Camarero JJ, Anderegg WRL, Vicente-Serrano SM (2017) Impacts of droughts on the growth resilience of Northern Hemisphere forests. Glob Ecol Biogeogr 26: 166-176

* Greve P, Orlowsky B, Mueller B, Sheffield J, Reichstein M, Seneviratne SI (2014) Global assessment of trends in wetting and drying over land. Nat Geosci 7:716-721

* Grierson CS, Barnes SR, Chase MW, Clarke M and others (2011) One hundred important questions facing plant science research. New Phytol 192:6-12

Gudmundsson L, Seneviratne SI (2016) Anthropogenic climate change affects meteorological drought risk in Europe. Environ Res Lett 11:044005

Haile M (2005) Weather patterns, food security and humanitarian response in sub-Saharan Africa. Philos Trans R Soc B 360:2169-2182

Hartmann DL (2015) Pacific sea surface temperature and the winter of 2014. Geophys Res Lett 42:1894-1902

Hayes MJ, Svoboda MD, Wardlow BD, Anderson MC, Kogan F (2012) Drought monitoring: historical and current perspectives. In: Wardlow BD, Anderson MC, Verdin JP (eds) Remote sensing of drought: innovative monitoring approaches. CRC Press/Taylor and Francis, Boca Raton, FL, p 1-19

Held IM, Soden BJ (2006) Robust responses of the hydrological cycle to global warming. J Clim 19:5686-5699

* Hlavinka P, Trnka M, Semerádová D, Dubrovský M, Žalud Z, Možný M (2009) Effect of drought on yield variability of key crops in Czech Republic. Agric Meteorol 149: 431-442

*Hoerling M, Eischeid J, Perlwitz J, Quan X, Zhang T, Pegion $P$ (2012) On the increased frequency of Mediterranean drought. J Clim 25:2146-2161 
Huang S, Huang Q, Chang J, Leng G (2016) Linkages between hydrological drought, climate indices and human activities: a case study in the Columbia River basin. Int $\mathrm{J}$ Climatol 36:280-290

Hunt ED, Svoboda M, Wardlow B, Hubbard K, Hayes M, Arkebauer T (2014) Monitoring the effects of rapid onset of drought on non-irrigated maize with agronomic data and climate-based drought indices. Agric Meteorol 191: $1-11$

Ivits E, Horion S, Erhard M, Fensholt R (2016) Assessing European ecosystem stability to drought in the vegetation growing season. Glob Ecol Biogeogr 25:1131-1143

Jerez SS, Trigo RM, Vicente-Serrano SM, Pozo-Vázquez DD and others (2013) The impact of the North Atlantic Oscillation on renewable energy resources in southwestern Europe. J Appl Meteorol Climatol 52:2204-2225

K Lejeune Q, Seneviratne SI, Davin EL (2017) Historical landcover change impacts on climate: comparative assessment of LUCID and CMIP5 multimodel experiments. J Clim 30:1439-1459

Lesk C, Rowhani P, Ramankutty N (2016) Influence of extreme weather disasters on global crop production. Nature 529:84-87

Ljungqvist FC (2017) Human and societal dimensions of past climate change. In: Crumley C, Lennarsson T, Westin A (eds) Issues and concepts in historical ecology: if the past teaches, what does the future learn? Cambridge University Press, Cambridge, in press

Ljungqvist FC, Krusic PJ, Sundqvist HS, Zorita E, Brattström G, Frank D (2016) Northern Hemisphere hydroclimate variability over the past twelve centuries. Nature 532: 94-98

Lloyd-Hughes B (2014) The impracticality of a universal drought definition. Theor Appl Climatol 117:607-611

Lobell DB, Schlenker W, Costa-Roberts J (2011) Climate trends and global crop production since 1980. Science 333:616-620

Lobell DB, Hammer GL, McLean G, Messina C, Roberts MJ, Schlenker W (2013) The critical role of extreme heat for maize production in the United States. Nat Clim Chang 3:497-501

* Lobell DB, Roberts MJ, Schlenker W, Braun N, Little BB, Rejesus RM, Hammer GL (2014) Greater sensitivity to drought accompanies maize yield increase in the U.S. Midwest. Science 344:516-519

Lobell DB, Hammer GL, Chenu K, Zheng B, McLean G, Chapman SC (2015) The shifting influence of drought and heat stress for crops in northeast Australia. Glob Change Biol 21:4115-4127

* López BC, Gracia CA, Sabaté S, Keenan T (2009) Assessing the resilience of Mediterranean holm oaks to disturbances using selective thinning. Acta Oecol 35:849-854

López-Moreno JI, Vicente-Serrano SM, Beguería S, GarcíaRuiz JM, Portela MM, Almeida AB (2009) Downstream propagation of hydrological droughts in highly regulated transboundary rivers: the case of the Tagus River between Spain and Portugal. Water Resour Res 45: W02405

López-Moreno JI, Vicente-Serrano SM, Zabalza J, Beguería S, Lorenzo-Lacruz J, Azorin-Molina C, Morán-Tejeda E (2013) Hydrological response to climate variability at different time scales: a study in the Ebro basin. J Hydrol (Amst) 477:175-188

Marengo JA, Tomasella J, Alves LM, Soares WR, Rodriguez DA (2011) The drought of 2010 in the context of historical droughts in the Amazon region. Geophys Res Lett 38: L12703

*Martínez-Fernández J, González-Zamora A, Sánchez N, Gumuzzio A, Herrero-Jiménez CM (2016) Satellite soil moisture for agricultural drought monitoring: assessment of the SMOS derived Soil Water Deficit Index. Remote Sens Environ 177:277-286

McCabe GJ, Palecki MA, Betancourt JL (2004) Pacific and Atlantic Ocean influences on multidecadal drought frequency in the United States. Proc Natl Acad Sci USA 101: 4136-4141

* McLeman RA, Dupre J, Berrang Ford L, Ford J, Gajewski K, Marchildon G (2014) What we learned from the Dust Bowl: lessons in science, policy, and adaptation. Popul Environ 35:417-440

Meehl GA, Karl T, Easterling DR, Changnon S and others (2000) An introduction to trends in extreme weather and climate events: observations, socioeconomic impacts, terrestrial ecological impacts, and model projections. Bull Am Meteorol Soc 81:413-416

* Mohino E, Janicot S, Bader J (2011) Sahel rainfall and decadal to multidecadal sea surface temperature variability. Clim Dyn 37:419-440

Mortimore M (ed) (1989) Adapting to drought: farmers, famines and desertification in West Africa. Cambridge University Press, Cambridge

* Nasrollahi N, AghaKouchak A, Cheng L, Damberg L and others (2015) How well do CMIP5 climate simulations replicate historical trends and patterns of meteorological droughts? Water Resour Res 51:2847-2864

Nathan MA, Fratkin EM, Roth EA (1996) Sedentism and child health among Rendille pastoralists of northern Kenya. Soc Sci Med 43:503-515

*Nicholson SE, Tucker CJ, Ba MB (1998) Desertification, drought and surface vegetation: an example from the west African Sahel. Bull Am Meteorol Soc 79:815-829

Nicolai-Shaw N, Gudmundsson L, Hirschi M, Seneviratne SI (2016) Long-term predictability of soil moisture dynamics at the global scale: persistence versus large-scale drivers. Geophys Res Lett 43:8554-8562

Oglesby R, Feng S, Hu Q, Rowe C (2012) The role of the Atlantic Multidecadal Oscillation on medieval drought in North America: synthesizing results from proxy data and climate models. Global Planet Change 84-85:56-65

* Olesen JE, Trnka M, Kersebaum KC, Skjelvåg AO and others (2011) Impacts and adaptation of European crop production systems to climate change. Eur J Agron 34:96-112

* Parry S, Wilby RL, Prudhomme C, Wood PJ (2016a) A systematic assessment of drought termination in the United Kingdom. Hydrol Earth Syst Sci 20:4265-4281

* Parry S, Prudhomme C, Wilby RL, Wood PJ (2016b) Drought termination: concept and characterization. Prog Phys Geogr 40:743-767

* Penrod J, Preston DB, Cain RE, Starks MT (2003) A discussion of chain referral as a method of sampling hard-toreach populations. J Transcult Nurs 14:100-107

*Petrokofsky G, Brown ND, Hemery GE (2013) Matching a scientific knowledge base with stakeholders' needs. For Policy Econ 37:29-36

*Pfister C, Weingartner R, Luterbacher J (2006) Reconstruction of extreme hydrological winter droughts over the last 450 years in the Upper Rhine basin: a methodological approach. Hydrol Sci J 51:966-985

* Potopová V, Štěpánek P, Možný M, Türkott L, Soukup J (2015) Performance of the standardized precipitation 
evapotranspiration index at various lags for agricultural drought risk assessment in the Czech Republic. Agric Meteorol 202:26-38

*Pretty J, Sutherland WJ, Ashby J, Auburn J and others (2010) The top 100 questions of importance to the future of global agriculture. Int J Agric Sustain 8:219-236

Rey D, Holman I, Knox J (2017) Developing drought resilience in irrigated agriculture in the face of increasing water scarcity. Reg Environ Change 17:1527-1540

Reyer CPO, Brouwers N, Rammig A, Brook BW and others (2015) Forest resilience and tipping points at different spatio-temporal scales: approaches and challenges. J Ecol 103:5-15

Rippey BR (2015) The U.S. drought of 2012. Weather Clim Extrem 10:57-64

Sánchez N, González-Zamora Á, Piles M, Martínez-Fernández J (2016) A new Soil Moisture Agricultural Drought Index (SMADI) integrating MODIS and SMOS products: a case of study over the Iberian Peninsula. Remote Sens 8:287

Schwab JC (2013) Planning and drought. American Planning Association planning advisory service report 574 . APA, Chicago, IL

Seager R, Hoerling $M$, Schubert S, Wang $H$ and others (2015) Causes of the 2011-14 California drought. J Clim 28:6997-7024

Seddon AWR, Mackay AW, Baker AG, Birks HJB and others (2014) Looking forward through the past: identification of 50 priority research questions in palaeoecology. J Ecol 102:256-267

Seneviratne SI, Nicholls N, Easterling D, Goodess CM and others (2012) Changes in climate extremes and their impacts on the natural physical environment. In: Field CB, Barros V, Stocker TF, Qin D and others (eds) A special report of Working Groups I and II of the Intergovernmental Panel on Climate Change (IPCC). Cambridge University Press, Cambridge, p 109-230

Sheffield J, Wood EF, Roderick ML (2012) Little change in global drought over the past 60 years. Nature 491: 435-438

Sinha A, Stott L, Berkelhammer M, Cheng $\mathrm{H}$ and others (2011) A global context for megadroughts in monsoon Asia during the past millennium. Quat Sci Rev 30:47-62

Smerdon JE, Luterbacher J, Phipps S, Anchukaitis KJ, Hydro2k Consortium (2017) Comparing proxy and model estimates of hydroclimate variability and change over the Common Era. Clim Past 13:1851-1900

Spinoni J, Naumann G, Vogt J (2015) Spatial patterns of European droughts under a moderate emission scenario. Adv Sci Res 12:179-186

Stagge JH, Kohn I, Tallaksen LM, Stahl K (2015) Modeling drought impact occurrence based on meteorological drought indices in Europe. J Hydrol (Amst) 530:37-50

Stahl K, Blauhut V, Kohn I, Acácio V and others (2012) A European Drought Impact Report Inventory (EDII): design and test for selected recent droughts in Europe. Tech Rep 3. DROUGHT-R\&SPI, Freiburg

Stahl K, Kohn I, Blauhut V, Urquijo J and others (2016) Impacts of European drought events: insights from an international database of text-based reports. Nat Hazards Earth Syst Sci 16:801-819

Sutherland WJ, Armstrong-Brown S, Armsworth PR, Brereton $\mathrm{T}$ and others (2006) The identification of 100 ecological questions of high policy relevance in the UK. J Appl Ecol 43:617-627

Sutherland WJ, Adams WM, Aronson RB, Aveling R and others (2009) One hundred questions of importance to the conservation of global biological diversity. Conserv Biol 23:557-567

Sutherland WJ, Fleishman E, Mascia MB, Pretty J, Rudd MA (2011) Methods for collaboratively identifying research priorities and emerging issues in science and policy. Methods Ecol Evol 2:238-247

Sutherland WJ, Freckleton RP, Godfray HCJ, Beissinger SR and others (2013) Identification of 100 fundamental ecological questions. J Ecol 101:58-67

* Svoboda M, LeComte D, Hayes M, Heim R and others (2002) The drought monitor. Bull Am Meteorol Soc 83: 1181-1190

Tadesse T, Wardlow BD, Hayes MJ, Svoboda MD, Brown JF (2010) The Vegetation Outlook (VegOut): a new method for predicting vegetation seasonal greenness. GISci Remote Sens 47:25-52

Tadesse T, Haigh T, Wall N, Shiferaw A and others (2016) Linking seasonal predictions to decision-making and disaster management in the Greater Horn of Africa. Bull Am Meteorol Soc 97:ES89-ES92

* Trenberth KE, Dai A, van der Schrier G, Jones PD, Barichivich J, Briffa KR, Sheffield J (2014) Global warming and changes in drought. Nat Clim Chang 4:17-22

Trigo RM, Añel J, Barriopedro D, García-Herrera R and others (2013) The record winter drought of 2011-12 in the Iberian Peninsula, in explaining extreme events of 2012 from a climate perspective. Bull Am Meteorol Soc 94: S41-S45

* Trnka M, Kyselý J, Možný M, Dubrovský M (2009) Changes in Central-European soil-moisture availability and circulation patterns in 1881-2005. Int J Climatol 29:655-672

* Trnka M, Brázdil R, Balek J, Semerádová D and others (2015) Drivers of soil drying in the Czech Republic between 1961 and 2012. Int J Climatol 35:2664-2675

*Van Loon AF, Stahl K, Di Baldassarre G, Clark J and others (2016) Drought in a human-modified world: reframing drought definitions, understanding, and analysis approaches. Hydrol Earth Syst Sci 20:3631-3650

*van Mantgem PJ, Stephenson NL, Byrne JC, Daniels LD and others (2009) Widespread increase of tree mortality rates in the western United States. Science 323:521-524

*Vicente-Serrano SM, Beguería S, López-Moreno JI (2010) A multiscalar drought index sensitive to global warming: the Standardized Precipitation Evapotranspiration Index. J Clim 23:1696-1718

*Vicente-Serrano SM, López-Moreno JI, Gimeno L, Nieto R and others (2011a) A multiscalar global evaluation of the impact of ENSO on droughts. J Geophys Res 116:D20109

*Vicente-Serrano SM, Beguería S, López-Moreno JI (2011b) Comment on 'Characteristics and trends in various forms of the Palmer Drought Severity Index (PDSI) during 1900-2008' by Aiguo Dai. J Geophys Res 116:D19112

* Vicente-Serrano SM, Zouber A, Lasanta T, Pueyo Y (2012a) Dryness is accelerating degradation of vulnerable shrublands in semiarid Mediterranean environments. Ecol Monogr 82:407-428

Vicente-Serrano SM, Beguería S, Lorenzo-Lacruz J, Camarero JJ and others (2012b) Performance of drought indices for ecological, agricultural, and hydrological applications. Earth Interact 16:1-27

Vicente-Serrano SM, Gouveia C, Camarero JJ, Beguería S and others (2013) The response of vegetation to drought time-scales across global land biomes. Proc Natl Acad Sci USA 110:52-57 
Vicente-Serrano SM, Lopez-Moreno JI, Beguería S, Lorenzo-Lacruz J and others (2014) Evidence of increasing drought severity caused by temperature rise in southern Europe. Environ Res Lett 9:044001

Vicente-Serrano SM, van der Schrier G, Beguería S, AzorinMolina C, Lopez-Moreno JI (2015) Contribution of precipitation and reference evapotranspiration to drought indices under different climates. J Hydrol (Amst) 526: 42-54

Vins H, Bell J, Saha S, Hess JJ (2015) The mental health outcomes of drought: a systematic review and causal process diagram. Int $\mathrm{J}$ Environ Res Public Health 12: 13251-13275

Walzer C, Kowalczyk C, Alexander JM, Baur B and others (2013) The 50 most important questions relating to the maintenance and restoration of an ecological continuum in the European Alps. PLOS ONE 8:e53139

Wang H, Vicente-Serrano SM, Tao F, Zhang X and others (2016) Monitoring winter wheat drought threat in Northern China using multiple climate-based drought indices and soil moisture during 2000-2013. Agric For Meteorol 228-229:1-12

Wetter O, Pfister C, Werner JP, Zorita E and others (2014) The year-long unprecedented European heat and drought of 1540 - a worst case. Clim Chang 125:349-363

Wilhite DA (1991) Drought planning: a process for state government. Water Resour Bull 27:29-38

Wilhite DA (2000) Drought as a natural hazard: concepts and definitions. In: Wilhite DA (ed) Drought: a global assessment. Routledge, London, p 3-18

Wilhite DA, Glantz MH (1985) Understanding the drought phenomenon: the role of definitions. Paper 20, Drought

Editorial responsibility: Gerrit Hoogenboom, Gainesville, Florida, USA
Mitigation Center Faculty Publications, University of Nebraska, Lincoln, NE

Wilhite DA, Hayes MJ, Knutson C (2005) Drought preparedness planning: building institutional capacity. In: Wilhite DA (ed) Drought and water crises: science, technology, and management issues. CRC Press/Taylor and Francis, Boca Raton, FL, p 93-135

Wilhite DA, Svoboda MD, Hayes MJ (2007) Understanding the complex impacts of drought: a key to enhancing drought mitigation and preparedness. Water Resour Manag 21:763-774

Williams AP, Allen CD, Macalady AK, Griffin D and others (2013) Temperature as a potent driver of regional forest drought stress and tree mortality. Nat Clim Chang 3: 292-297

(WMO) World Meteorological Organization (2006) Drought monitoring and early warning: concepts, progress and future challenges. Document No 1006. WMO, Geneva

WMO, GWP (Global Water Partnership) (2016) Handbook of drought indicators and indices (M. Svoboda and B. A. Fuchs). Integrated drought management tools and guidelines, Series 2. Integrated Drought Management Programme (IDMP), Geneva

WMO, GWP (2017) Benefits of action and costs of inaction: drought mitigation and preparedness - a literature review (N. Gerber and A. Mirzabaev). Working Paper 1. Integrated Drought Management Programme (IDMP), Geneva

Y Yang B, Kang S, Ljungqvist FC, He M, Zhao Y, Qin C (2014) Drought variability at the northern fringe of the Asian summer monsoon region over the past millennia. Clim Dyn 43:845-859

Submitted: July 11, 2017; Accepted: January 24, 2018

Proofs received from author(s): August 15, 2018 